\title{
Chemical Evaluation of Trace Elements in Bottled Water
}

\author{
Bikram Gautam (1D) \\ ${ }^{1}$ Research Center for Applied Science and Technology (RECAST), Tribhuvan University, Kirtipur, Nepal \\ ${ }^{2}$ Department of Microbiology, St. Xavier's College, Maitighar, Kathmandu, Nepal \\ Correspondence should be addressed to Bikram Gautam; gautambikr@gmail.com
}

Received 26 August 2020; Revised 11 November 2020; Accepted 21 November 2020; Published 3 December 2020

Academic Editor: Ayush Dogra

Copyright (c) 2020 Bikram Gautam. This is an open access article distributed under the Creative Commons Attribution License, which permits unrestricted use, distribution, and reproduction in any medium, provided the original work is properly cited.

Sales of bottled water have been increasing around the globe. This study was carried out to assess the trace elements present in bottled water. For the study of bottled water, a total of 100 samples of different volumes $(20 \mathrm{~L}$ and $1 \mathrm{~L})$ were selected. The physicochemical assessments were performed as per the methods described in the American Public Health Association, 2005. Average values of $\mathrm{pH}$, electrical conductivity, total dissolved solids, and turbidity were found to be $5.96 \pm 0.54,59.97 \pm 58.65$, $4.42 \pm 3.69$, and $0.408 \pm 0.19$, respectively. Likewise, average values of total hardness $\left(\right.$ as $\left.\mathrm{CaCO}_{3}\right)$, calcium (as $\left.\mathrm{CaCO}_{3}\right)$, magnesium (as $\mathrm{CaCO}_{3}$ ), chlorine, iron, copper, cobalt, nickel, fluoride, sodium, and potassium were found to be $14.78 \pm 8.43,3.26 \pm 1.55$, $11.51 \pm 7.92,7.51 \pm 3.21,0.0032 \pm 0.0017,0.0091 \pm 0.0116,0.2520 \pm 0.0127,0.0080 \pm 0.0082,0.047 \pm 0.0139,12.65 \pm 10.90$, and $1.41 \pm 2.00$, respectively; meanwhile residual chlorine, zinc, silver, cadmium, and lead were below detection limit. All the physicochemical characteristics of bottled water were found to be within International Bottled Water Association (IBWA) guidelines. From the physicochemical aspects, the bottled water was found to be within the permissible value set by IBWA. Pearson's correlation revealed significant association between trace elements. Levene's test for equity of variances indicated that the majority (iron, copper, cobalt, nickel, fluoride, sodium, and potassium) of trace elements and seasons (monsoon and postmonsoon) demonstrated a statistically significant distribution (at 95\% confidence interval). At elevated concentrations, some elements can be harmful to human health and can cause morphological abnormalities, mutagenic effects, reduced growth, and increased morbidity and mortality in humans but it all depends upon a person's metabolic factors, genetic factors, and ability to excrete trace elements through different routes, etc. Water could have percolated down from the surface to the ground water and as such the difference in concentration of trace elements in monsoon and postmonsoon seasons could be noticeable.

\section{Introduction}

Water is known as a universal solvent and even in its natural state it may contain substantial quantities of chemical elements [1, 2]. Anthropogenic contaminants (e.g., pesticides, fertilizers, and nutrients) and industrial chemicals (e.g., hydrocarbon derivatives and heavy metals) can also be found in the water [3-6]. Chemical contaminants in drinking water pose health risks for infants, the elderly, and people with weakened immune systems due to viral infections, immune disorders, cancer, chemotherapy, or recent organ transplantation [7-9]. A study conducted in California found 38 pollutants in 10 bottled water brands [10].

Inorganic substances (heavy metals and macro inorganic elements such as nitrate/nitrite) in water have received most of the attention because of their potentially harmful effects $[7,11]$. At elevated concentrations, some elements can be harmful to human health and can cause morphological abnormalities, mutagenic effects, reduced growth, and increased mortality in humans [12]. The presence of organics, radionuclides, nitrates, and nitrites in drinking water can lead to cancer, other human body malfunctions, and chronic illness [13]. Several trace elements ( $\mathrm{Ag}, \mathrm{Be}, \mathrm{Li}, \mathrm{Ge}, \mathrm{Sb}, \mathrm{Sc}, \mathrm{Te}$, $\mathrm{Th}$, and $\mathrm{U}$ ) are not monitored in bottled waters $[1,2]$. As a result, there are extremely limited data on the abundance and potential health impact of many toxic trace elements $[12,14]$.

The outcomes of this study are expected to increase the public's understanding of water and the nutrients it contains. This study also hopes to enlighten the governmental 
bodies, water bottle industries, and license-providing authoritative bodies like International Bottled Water Association (IBWA) and Department of Food Technology and Quality Control (DFTQC) regarding the importance of excess trace elements in bottled water.

The aim of this study is to assess some of the important physical and chemical properties of bottled water in comparison to the IBWA guidelines.

\section{Methodology}

2.1. Study Site. The study was performed in the Department of Microbiology, St. Xavier's College, Maitighar; the Research Center for Applied Science and Technology, Tribhuvan University, Kirtipur; and the Department of Mines and Geology, Ministry of Industry, Lazimpat. The study was conducted from July 2017 through September 2017.

2.2. Sample Selection, Size, Collection, Transportation, and Storage. For the bottled water study, both $20 \mathrm{~L}$ and $1 \mathrm{~L}$ bottles were selected and processed in both monsoon and postmonsoon seasons. A total of 100 samples were selected for the study.

Bottled water in $20 \mathrm{~L}$ containers was purchased in the market. After shaking the bottle, the seal was opened in the market/retailer and the neck was sterilized by $70 \%$ ethanol. Four sterilized polypropylene bottles were filled, leaving headspace, and were labeled.

Four 1L bottles of water were purchased from the market. The collected samples were kept in mini cooler with ice packs and transported to the laboratory to be processed.

\section{Assessment of Physical Parameters}

3.1. $\mathrm{pH}$. $\mathrm{pH}$ meter (calibrated by using buffer solutions of $\mathrm{pH} 4.0,7.0$, and 9.0) was used to determine the $\mathrm{pH}$ of water samples [15].

3.2. Electric Conductivity. Conductivity meter (calibrated by using standard sodium chloride solution of $19880 \mu \mathrm{S} / \mathrm{cm}$ ) was used to determine the conductivity [15].

3.3. Total Dissolved Solid. $100 \mathrm{ml}$ of water was filtered through membrane filter and then it was subjected to heat in a porcelain basin of known weight at $110^{\circ} \mathrm{C}$ in hot air oven and the basin was transferred to white silica containing desiccator. The change in weight was determined [15].

3.4. Turbidity. Nephelometer (calibrated with Formazin standard solutions of 0.2 NTU, 10 NTU, 100 NTU, and 1000 NTU) was used to measure the turbidity of water samples by filling in the clean and chemical leached dry cuvette [15].

\section{Assessment of Chemical Parameters}

4.1. Total Hardness. Measured volume of $2 \mathrm{~mL}$ buffer solution of ammonium chloride and ammonium hydroxide was added to $50 \mathrm{~mL}$ of the water samples. A change in color was observed and the solution was titrated against EDTA in the presence of the indicator Eriochrome Black T [15]. The Total hardness was calculated as

$$
\text { total hardness }(\mathrm{mg} / L)=\frac{V * 1000}{v},
$$

where $V$ is $\mathrm{ml}$ of EDTA consumed and $v$ is volume of sample.

4.2. Calcium. Measured volume of $1 \mathrm{ml}$ sodium hydroxide solution was added to $50 \mathrm{~mL}$ of water sample and $0.2 \mathrm{~g}$ solution (ammonium purpurate and sodium chloride). A change in color was observed and the solution was titrated against EDTA in the presence of the indicator $\mathrm{NaOH}$ solution [15]. Calcium was calculated as

$$
\text { calcium hardness }(\mathrm{mg} / L)=\frac{V * 400.8}{v},
$$

where $V$ is ml of EDTA consumed and $v$ is volume of sample.

4.3. Magnesium. The value of calcium (as $\mathrm{CaCO}_{3}$ ) was deducted from total hardness $\left(\right.$ as $\mathrm{CaCO}_{3}$ ) [15]. Magnesium was calculated as

Magnesium (as $\left.\mathrm{CaCO}_{3}\right)(\mathrm{mg} / \mathrm{L})=$ Total hardness $($ as $\mathrm{CaCO}_{3}$ ) - Calcium (as $\mathrm{CaCO}_{3}$ ).

4.4. Chloride. After adjusting the $\mathrm{pH}$ of water between 7 and 10 (with the addition of $\mathrm{H}_{2} \mathrm{SO}_{4}$ and $\mathrm{NaOH}$ ), $50 \mathrm{~mL}$ of water was titrated against $\mathrm{AgNO}_{3}$ in the presence of indicator $\mathrm{K}_{2} \mathrm{Cr}_{2} \mathrm{O}_{4}$ and change in color was noticed [15]. The process was repeated for blank. Chloride was calculated as

$$
\text { chloride }(\mathrm{mg} / L)=\frac{(A-B) * S * 35.5 * 1000}{v},
$$

where $A$ denotes $\mathrm{AgNO}_{3}$ consumed by sample, $B$ denotes $\mathrm{AgNO}_{3}$ consumed by blank, $S$ denotes strength of $\mathrm{AgNO}_{3}$, and $v$ denotes volume of sample.

4.5. Residual Chlorine. In a clean and chemical leached conical flask, $5 \mathrm{~mL}$ acetic acid and $50 \mathrm{~mL}$ sample were mixed. $1 \mathrm{~mL}$ of potassium iodide was added in the solution which was titrated against $0.025 \mathrm{~N} \mathrm{Na}_{2} \mathrm{~S}_{2} \mathrm{O}_{3}$. After adding starch solution, titration was again done against $0.025 \mathrm{~N} \mathrm{Na}_{2} \mathrm{~S}_{2} \mathrm{O}_{3}$ [15]. As a quality control blank was run using the same methodology. Residual chlorine was calculated as

$$
\text { residual chlorine }(\mathrm{mg} / L)=\frac{V * S * 35.46 * 1000}{v},
$$

where $S$ denotes strength of $\mathrm{Na}_{2} \mathrm{~S}_{2} \mathrm{O}_{3}, \mathrm{~V}$ denotes volume of $\mathrm{Na}_{2} \mathrm{~S}_{2} \mathrm{O}_{3}$ consumed, and $v$ denotes volume of sample. 
4.6. Fluoride. First value was set to 0 at $570 \mathrm{~nm}$ with the help of reference solution. The absorbance was taken in a clean, chemical leached cuvette containing $5 \mathrm{~mL}$ water and $50 \mu \mathrm{L}$ $\mathrm{NaAsO}_{2}$ [15]. As a quality control blank was run using the same methodology.

4.7. Sodium and Potassium. After calibrating the flame photometer at $589 \mathrm{~nm}$ for sodium and $768 \mathrm{~nm}$ for potassium ( $\mathrm{NaCl}$ solutions of standards 2, 4, 6, 8, and $10 \mathrm{mg} / \mathrm{L} ; \mathrm{KCl}$ solution of standards $2,4,6,8$, and $10 \mathrm{mg} / \mathrm{L})$, respectively, $5 \mathrm{ml}$ water sample was taken in a clean, chemical leached, and dry tube. In case of excess concentration of sodium in the sample, dilution was done with deionized water and dilution factor was applied to the obtained value in flame photometer [15].

4.8. Trace Elements. About $500 \mathrm{~mL}$ water filtered using membrane filter was stored in $4^{\circ} \mathrm{C}$ in a chemical leached bottle. The heavy metals were detected using Flame Atomic Absorption Spectroscopy (FAAS) AA-7000 manufactured by Shimadzu, Japan, with ASC-7000 autosampler [15]. The instrumental parameters set for the analysis of the elements analyzed is tabulated separately as follows (Table 1).

The water samples were analyzed for each element mentioned in the above table under similar parameters described for corresponding elements and the concentration for each sample was determined by the software. $100 \mathrm{~mL}$ distilled water with 1-2 mL conc. $\mathrm{HNO}_{3}$ was taken as blank solution for the measurements.

4.9. Quality Control. Strict chemical leaching procedures were followed for quality control [4]. To obtain reliable physiochemical results, a sample was processed 3 times. Instruments and equipment were calibrated before use.

\section{Data Analysis}

Data analysis was done using Statistical Package for the Social Sciences (SPSS) version 19.

\section{Results}

A total of 100 samples of bottled water were collected according to their local availability and popularity in Kathmandu valley. The samples were examined for physicochemical parameters to assess the quality of bottled water. A total of 50 ( 25 monsoon and 25 postmonsoon) $20 \mathrm{~L}$ water bottles and 50 ( 25 monsoon and 25 postmonsoon) vessels of $1 \mathrm{~L}$ were examined in this study.

\section{Assessment of Physical Parameters of Water}

7.1. $\mathrm{pH}$. The $\mathrm{pH}$ of the bottled water ranged from 5.2 to 8.2 $(M=5.96, \mathrm{SD}=0.54)$. The $\mathrm{pH}$ ranges for $20 \mathrm{~L}$ water bottles in monsoon and postmonsoon seasons were found to be 5.2-6.6 $(M=5.88, \quad \mathrm{SD}=0.40)$ and 5.2-6.8 $\quad(M=5.94$, $\mathrm{SD}=0.41)$, respectively. The $\mathrm{pH}$ ranges for $1 \mathrm{~L}$ vessels in monsoon and postmonsoon seasons were found to be
5.2-8.0 $(M=5.94, \quad \mathrm{SD}=0.56)$ and 5.2-8.2 $(M=6.01$, $\mathrm{SD}=0.65)$, respectively. These results are presented in Table 2 and represented in Figure 1.

Levene's test for equity of variances indicated that the $\mathrm{pH}$ and seasons (monsoon and postmonsoon) demonstrated a statistically significant distribution ( $p=0.387$ at $95 \%$ confidence interval).

7.2. Electrical Conductivity (EC). Electrical conductivity of the bottled water ranged from $5 \mu \mathrm{S} / \mathrm{cm}$ to $199 \mu \mathrm{S} / \mathrm{cm}$ $(M=59.97 \mu \mathrm{S} / \mathrm{cm}, \mathrm{SD}=58.65)$. The electrical conductivity ranges for $20 \mathrm{~L}$ water bottles in monsoon and postmonsoon seasons were found to be $7 \mu \mathrm{S} / \mathrm{cm}-189 \mu \mathrm{S} / \mathrm{cm}(M=69.48 \mu \mathrm{S} /$ $\mathrm{cm}, \mathrm{SD}=67.58)$ and $5 \mu \mathrm{S} / \mathrm{cm}-199 \mu \mathrm{S} / \mathrm{cm}(M=61.10 \mu \mathrm{S} / \mathrm{cm}$, $\mathrm{SD}=62.34)$, respectively. The electrical conductivity ranges for $1 \mathrm{~L}$ vessels in monsoon and postmonsoon seasons were found to be $5 \mu \mathrm{S} / \mathrm{cm}-199 \mu \mathrm{S} / \mathrm{cm} \quad(M=56.24 \mu \mathrm{S} / \mathrm{cm}$, $\mathrm{SD}=58.93)$ and $5 \mu \mathrm{S} / \mathrm{cm}-191 \mu \mathrm{S} / \mathrm{cm} \quad(M=61.44 \mu \mathrm{S} / \mathrm{cm}$, $\mathrm{SD}=52.57)$, respectively. These results are presented in Table 2 and represented in Figure 2.

Pearson's correlation implies that there is a significant positive association between EC and TDS $(r=0.251)$, between EC and turbidity $(r=0.198)$, and between EC and chloride $(r=0.234)$, as seen in Table 3. Levene's test for equity of variances indicated that the EC and seasons (monsoon and postmonsoon) demonstrated a statistically significant distribution $(p=0.146$ at $95 \%$ confidence interval).

7.3. Total Dissolved Solid (TDS). Total dissolved solid of the bottled water ranged from $1 \mathrm{mg} / \mathrm{L}$ to $15 \mathrm{mg} / \mathrm{L}(M=4.42 \mathrm{mg} /$ $\mathrm{L}, \mathrm{SD}=3.69$ ). The total dissolved solid ranges for $20 \mathrm{~L}$ water bottles in monsoon and postmonsoon seasons were found to be $1 \mathrm{mg} / \mathrm{L}-15 \mathrm{mg} / \mathrm{L}(M=5.28 \mathrm{mg} / \mathrm{L}, \mathrm{SD}=3.88)$ and $1 \mathrm{mg} /$ $\mathrm{L}-15 \mathrm{mg} / \mathrm{L} \quad(M=4.44 \mathrm{mg} / \mathrm{L}, \mathrm{SD}=4.01)$, respectively. The total dissolved solid ranges for $1 \mathrm{~L}$ vessels in monsoon and postmonsoon seasons were found to be $1 \mathrm{mg} / \mathrm{L}-12 \mathrm{mg} / \mathrm{L}$ $(M=4.12 \mathrm{mg} / \mathrm{L}, \quad \mathrm{SD}=3.48) \quad$ and $\quad 1 \mathrm{mg} / \mathrm{L}-15 \mathrm{mg} / \mathrm{L}$ $(M=3.84 \mathrm{mg} / \mathrm{L}, \mathrm{SD}=3.42)$, respectively. These results are presented in Table 2 and represented in Figure 3.

Levene's test for equity of variances indicated that the TDS and seasons (premonsoon and postmonsoon) demonstrated a statistically significant distribution $(p=0.617$ at 95\% confidence interval).

7.4. Turbidity. Turbidity of the bottled water ranged from 0.2 NTU to $1.55 \mathrm{NTU}(M=0.408 \mathrm{NTU}, \mathrm{SD}=0.195)$. The turbidity ranges for $20 \mathrm{~L}$ water bottles in monsoon and postmonsoon seasons were found to be 0.2 NTU-1.55 NTU $(M=0.414$ NTU, SD $=0.257)$ and 0.2 NTU-1.55 NTU $(M=0.420 \mathrm{NTU}, \mathrm{SD}=0.255)$, respectively. The turbidity ranges for $1 \mathrm{~L}$ vessels in monsoon and postmonsoon seasons were found to be $0.2 \mathrm{NTU}-0.53 \mathrm{NTU}(M=0.380 \mathrm{NTU}$, $\mathrm{SD}=0.096)$ and $0.21 \mathrm{mg} / \mathrm{L}-0.58 \mathrm{mg} / \mathrm{L}(M=0.399 \mathrm{NTU}$, $\mathrm{SD}=0.121)$, respectively. All 100 samples had turbidity value at acceptable range as per IBWA guideline. These results are presented in Table 2 and represented in Figure 4. 
TABLE 1: Instrumental parameters set for the analysis of the trace elements in AA-7000 (F-AAS).

\begin{tabular}{lcccc}
\hline Elements & & & & \multicolumn{2}{c}{$\begin{array}{c}\text { Flow rate of air acetylene } \\
\text { flame (L/min) } \\
\text { Acetylene }\end{array}$} & $\begin{array}{c}\text { Lamp current (mA) } \\
\text { Air }\end{array}$ \\
\hline Iron & Wavelength (nm) & Slit width (nm) & 12 & 2.2 \\
Zinc & 248.3 & 0.2 & 8 & 1.8 \\
Silver & 213.9 & 0.7 & 2 & 0.9 \\
Copper & 328.1 & 0.2 & 8 & 1.8 \\
Cadmium & 324.8 & 0.7 & 4 & 1.2 \\
Cobalt & 228.8 & 0.7 & 12 & 1.6 \\
Nickel & 240.7 & 0.2 & 12 & 1.6 \\
Lead & 232.0 & 0.2 & 5 & 1.5 \\
\hline
\end{tabular}

L: liter(s); nm: nanometer; mA: milliamperes; min: minute.

TABLe 2: Association between physical parameters (as per IBWA guideline), volume of bottled water, and season.

\begin{tabular}{|c|c|c|c|c|c|c|c|}
\hline \multirow[t]{2}{*}{ Sn } & \multirow[t]{2}{*}{ Volume (L) } & \multirow[t]{2}{*}{ Physical parameter } & \multicolumn{2}{|c|}{ Monsoon season } & \multicolumn{2}{|c|}{$\begin{array}{l}\text { Postmonsoon } \\
\text { season }\end{array}$} & \multirow[t]{2}{*}{ Permissible value as per IBWA guideline } \\
\hline & & & $M \pm \mathrm{SD}$ & A & $M \pm \mathrm{SD}$ & A & \\
\hline 1 & $\begin{array}{c}1 \\
20\end{array}$ & $\mathrm{pH}$ & $\begin{array}{l}5.94 \pm 0.56 \\
5.96 \pm 0.54\end{array}$ & $\begin{array}{l}* \\
*\end{array}$ & $\begin{array}{c}6.01 \pm 0.65 \\
5.88 \pm 0.4\end{array}$ & $\begin{array}{l}* \\
*\end{array}$ & $6.5-8.5^{*}$ \\
\hline 2 & $\begin{array}{c}1 \\
20\end{array}$ & Electrical conductivity & $\begin{array}{l}56.24 \pm 58.93 \\
69.48 \pm 67.58\end{array}$ & NA & $\begin{array}{l}61.44 \pm 52.57 \\
61.10 \pm 62.34\end{array}$ & NA & NA \\
\hline 3 & $\begin{array}{c}1 \\
20\end{array}$ & Total dissolved solids & $\begin{array}{l}4.12 \pm 3.48 \\
5.28 \pm 3.88\end{array}$ & NA & $\begin{array}{l}3.84 \pm 3.42 \\
4.44 \pm 4.01\end{array}$ & NA & 500 \\
\hline 4 & $\begin{array}{c}1 \\
20 \\
\end{array}$ & Turbidity & $\begin{array}{c}0.38 \pm 0.096 \\
0.414 \pm 0.257\end{array}$ & $\begin{array}{l}25 \\
25\end{array}$ & $\begin{array}{c}0.399 \pm 0.121 \\
0.42 \pm 0.255\end{array}$ & $\begin{array}{l}25 \\
25\end{array}$ & 0.5 \\
\hline
\end{tabular}

NA: value not available in guideline; $M$ : mean; SD: standard deviation; A: acceptability. ${ }^{*}$ indicates guideline not enforceable by IBWA.

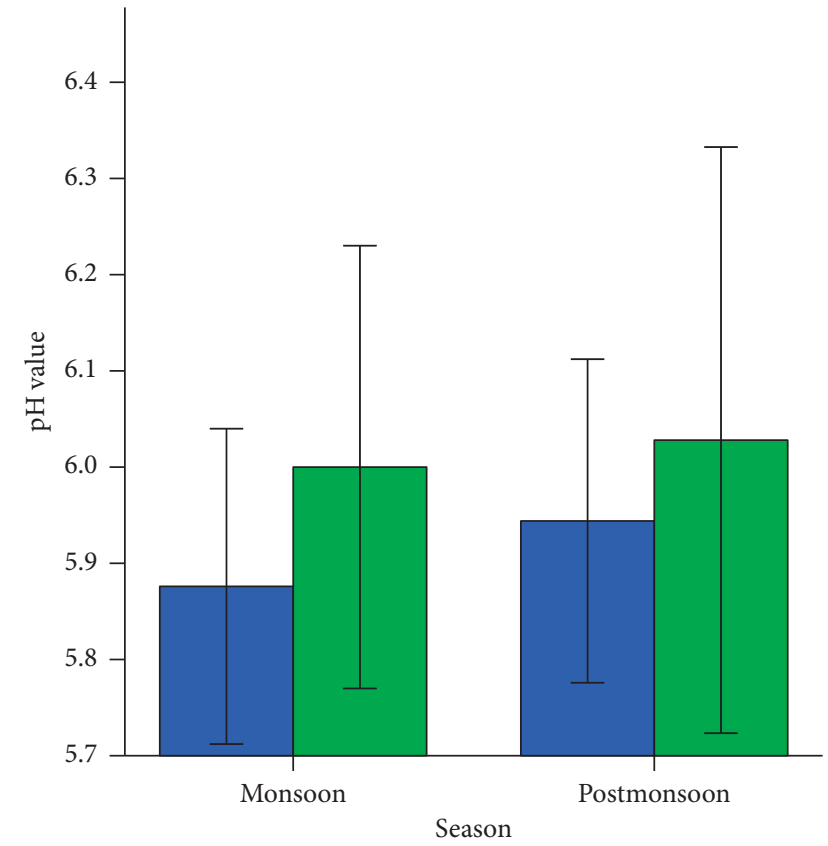

Sample from bottled water of

$\square 20$ liters

$\square 1$ liter

Figure 1: Distribution of $\mathrm{pH}$ value with respect to season and bottled water.

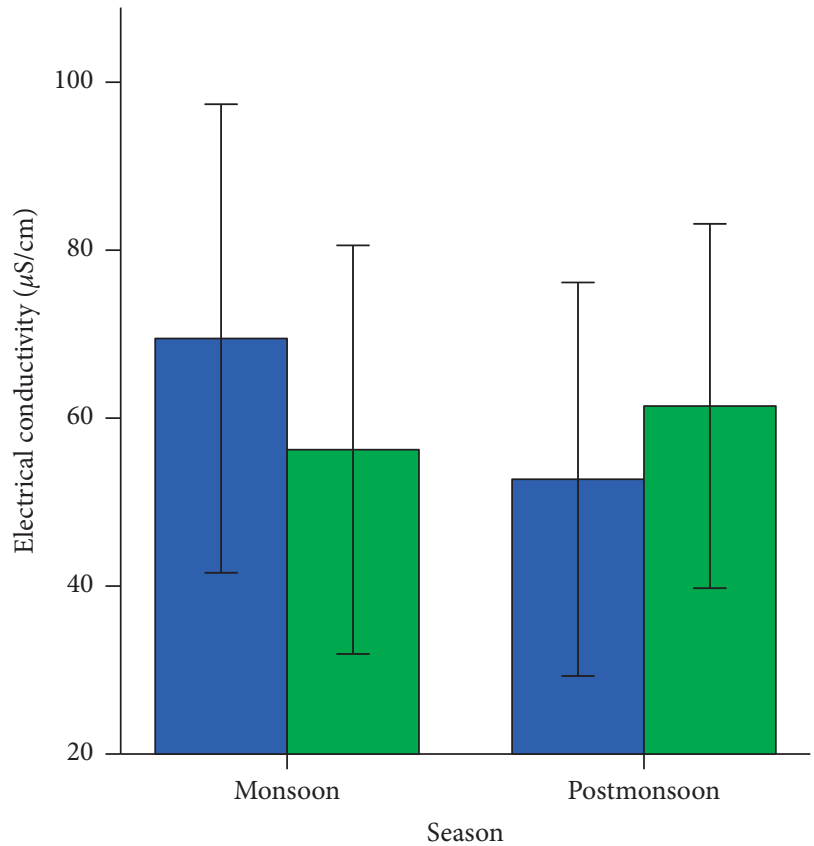

Sample from bottled water of

$$
\begin{aligned}
& \square 20 \text { liters } \\
& \square 1 \text { liter }
\end{aligned}
$$

Figure 2: Distribution of electrical conductivity value with respect to season and bottled water. 


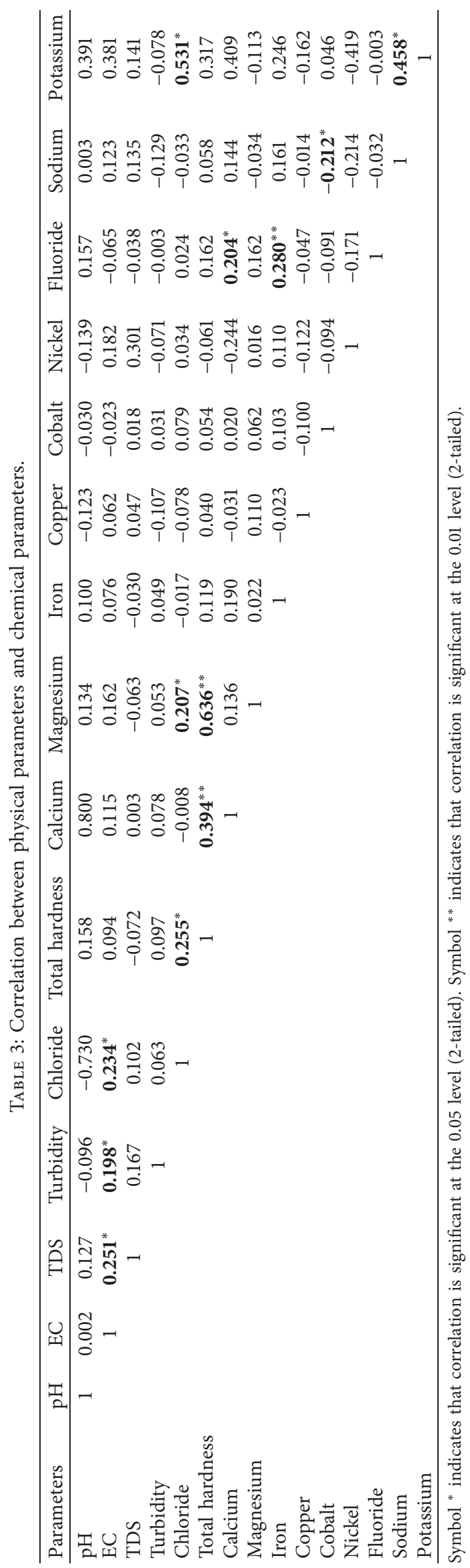




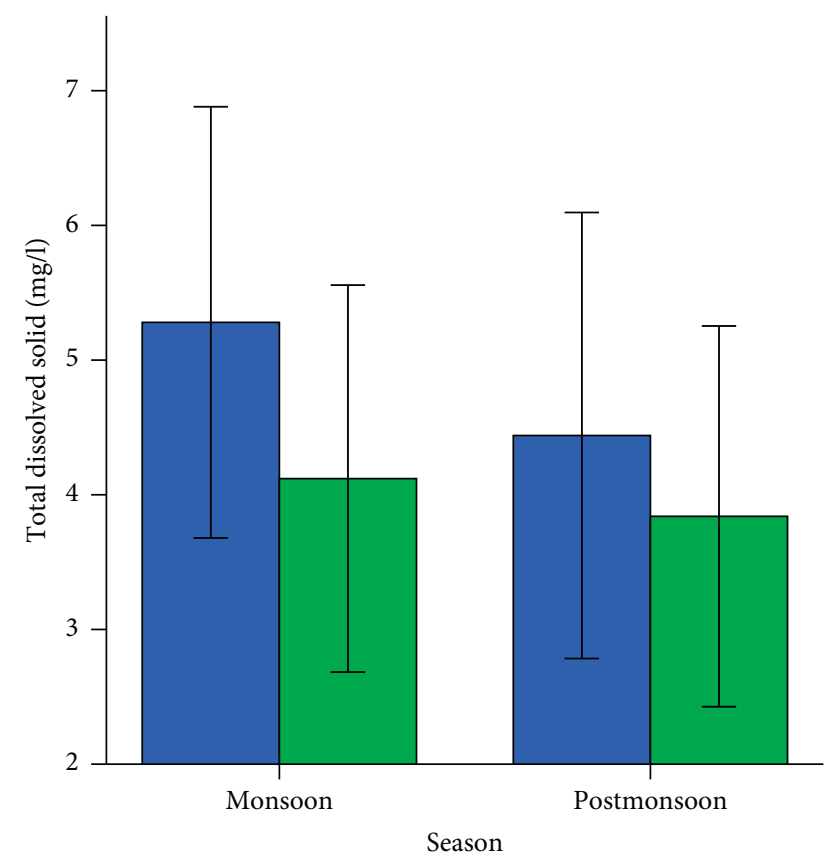

Sample from bottled water of $\square 20$ liters

$\square$ liter

Figure 3: Distribution of total dissolved solid value with respect to season and bottled water.

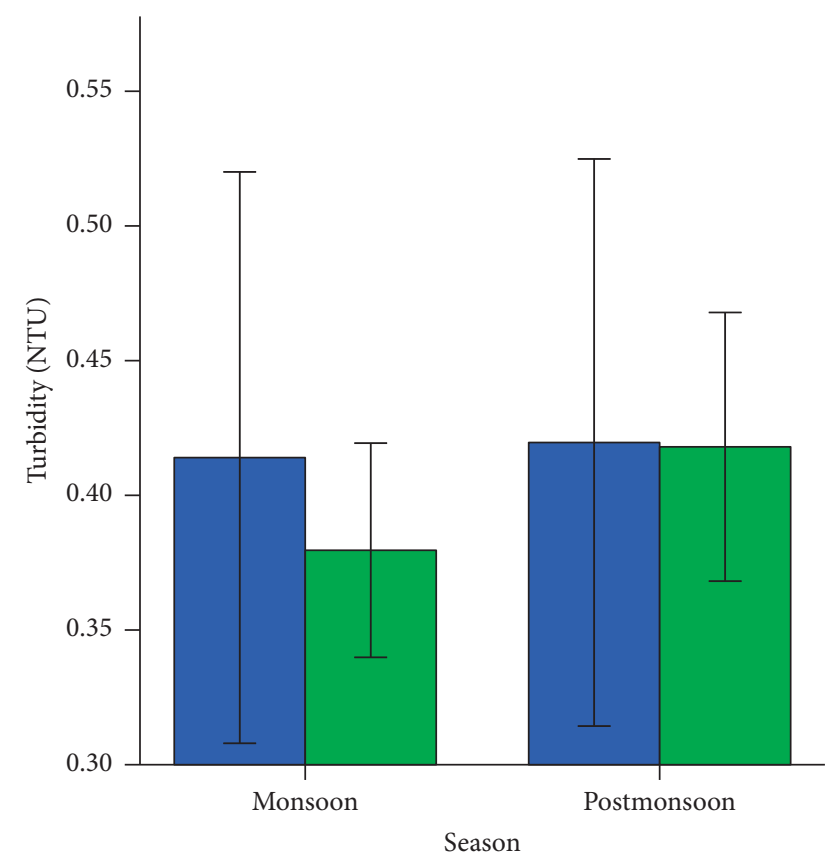

Sample from bottled water of

$\square 20$ liters

$\square 1$ liter

Figure 4: Distribution of turbidity value with respect to season and bottled water.
Levene's test for equity of variances indicated that the turbidity and seasons (monsoon and postmonsoon) demonstrated a statistically significant distribution $(p=0.688$ at 95\% confidence interval).

\section{Assessment of Chemical Parameters}

8.1. Total Hardness. Total hardness in the bottled water ranged from $0.8 \mathrm{mg} / \mathrm{L}$ to $31 \mathrm{mg} / \mathrm{L} \quad(M=14.78 \mathrm{mg} / \mathrm{L}$, $\mathrm{SD}=8.43)$. The total hardness ranges for $20 \mathrm{~L}$ water bottles in monsoon and postmonsoon seasons were found to be $4.9 \mathrm{mg} / \mathrm{L}-25.9 \mathrm{mg} / \mathrm{L} \quad(M=15.40 \mathrm{mg} / \mathrm{L}, \quad \mathrm{SD}=8.24) \quad$ and $4.7 \mathrm{mg} / \mathrm{L}-31.0 \mathrm{mg} / \mathrm{L} \quad(M=14.82 \mathrm{mg} / \mathrm{L}, \quad \mathrm{SD}=8.71)$, respectively. The total hardness ranges for $1 \mathrm{~L}$ vessels in monsoon and postmonsoon season were found to be $0.8 \mathrm{mg} /$ $\mathrm{L}-31.0 \mathrm{mg} / \mathrm{L} \quad(M=13.76 \mathrm{mg} / \mathrm{L}, \quad \mathrm{SD}=8.71) \quad$ and $2.8 \mathrm{mg} /$ L-31.0 mg/L $(M=15.14 \mathrm{mg} / \mathrm{L}, \mathrm{SD}=8.47)$, respectively. All 100 samples had total hardness concentration at acceptable range as per IBWA guideline. These results are presented in Table 4 and represented in Figure 5.

Pearson's correlation implies that there is a significant positive association between total hardness and calcium (as $\left.\mathrm{CaCO}_{3}\right)(r=0.394)$ and between total hardness and magnesium $\left(\right.$ as $\left.\mathrm{CaCO}_{3}\right)(r=0.636)$, as seen in Table 3. Levene's test for equity of variances indicated that the total hardness and seasons (monsoon and postmonsoon) demonstrated a statistically significant distribution ( $p=0.717$ at $95 \%$ confidence interval).

8.2. Calcium. Calcium (as $\mathrm{CaCo}_{3}$ ) in the bottled water ranged from $0.4 \mathrm{mg} / \mathrm{L}$ to $6.2 \mathrm{mg} / \mathrm{L} \quad(M=3.26 \mathrm{mg} / \mathrm{L}$, $\mathrm{SD}=1.55)$. The calcium $\left(\right.$ as $\left.\mathrm{CaCO}_{3}\right)$ ranges for $20 \mathrm{~L}$ water bottles in monsoon and postmonsoon seasons were found to be $\quad 0.4 \mathrm{mg} / \mathrm{L}-6.2 \mathrm{mg} / \mathrm{L} \quad(M=3.54 \mathrm{mg} / \mathrm{L}, \quad \mathrm{SD}=1.80) \quad$ and $1.2 \mathrm{mg} / \mathrm{L}-6.2 \mathrm{mg} / \mathrm{L}(M=3.01 \mathrm{mg} / \mathrm{L}, \mathrm{SD}=1.49)$, respectively. The calcium $\left(\mathrm{as} \mathrm{CaCO}_{3}\right.$ ) ranges for $1 \mathrm{~L}$ vessels in monsoon and postmonsoon seasons were found to be $0.4 \mathrm{mg} /$ $\mathrm{L}-6.2 \mathrm{mg} / \mathrm{L} \quad(M=2.90 \mathrm{mg} / \mathrm{L}, \quad \mathrm{SD}=1.41) \quad$ and $\quad 1.4 \mathrm{mg} /$ $\mathrm{L}-6.0 \mathrm{mg} / \mathrm{L}(M=3.58 \mathrm{mg} / \mathrm{L}, \mathrm{SD}=1.46)$, respectively. All 100 samples had calcium $\left(\right.$ as $\left.\mathrm{CaCO}_{3}\right)$ concentration at acceptable range as per IBWA guideline. These results are presented in Table 4 and represented in Figure 6.

Pearson's correlation implies that there is a significant positive association between calcium (as $\mathrm{CaCO}_{3}$ ) and fluoride $(r=0.204)$ as seen in Table 3 . Levene's test for equity of variances indicated that the calcium and seasons (monsoon and postmonsoon) demonstrated a statistically significant distribution ( $p=0.345$ at $95 \%$ confidence interval).

8.3. Magnesium. Magnesium (as $\mathrm{CaCo}_{3}$ ) in the bottled water ranged from $0.2 \mathrm{mg} / \mathrm{L}$ to $28.0 \mathrm{mg} / \mathrm{L} \quad(M=11.51 \mathrm{mg} / \mathrm{L}$, $\mathrm{SD}=7.92$ ). The magnesium $\left(\mathrm{as} \mathrm{CaCo}_{3}\right)$ ranges for $20 \mathrm{~L}$ water bottles in monsoon and postmonsoon seasons were found to be $1.4 \mathrm{mg} / \mathrm{L}-25.5 \mathrm{mg} / \mathrm{L}(M=11.86 \mathrm{mg} / \mathrm{L}, \mathrm{SD}=8.45)$ and $2.1 \mathrm{mg} /$ $\mathrm{L}-28.0 \mathrm{mg} / \mathrm{L} \quad(M=11.8 \mathrm{mg} / \mathrm{L}, \quad \mathrm{SD}=7.84)$, respectively. The 
TABle 4: Association between chemical parameters (as per IBWA guideline), volume of bottled water, and season.

\begin{tabular}{|c|c|c|c|c|c|c|c|c|c|}
\hline \multirow{2}{*}{ Sn } & \multirow{2}{*}{ Micronutrient } & \multirow{2}{*}{ Volume (L) } & \multicolumn{3}{|c|}{ Monsoon season } & \multicolumn{3}{|c|}{ Postmonsoon season } & \multirow{2}{*}{$\begin{array}{l}\text { Permissible value as per IBWA } \\
\text { guideline }\end{array}$} \\
\hline & & & $M \pm \mathrm{SD}$ & $\mathrm{D}$ & $\mathrm{A}$ & $M \pm \mathrm{SD}$ & $\mathrm{D}$ & $\mathrm{A}$ & \\
\hline 1 & Residual chlorine & $\begin{array}{c}1 \\
20\end{array}$ & & & NA & & & NA & 0.1 \\
\hline 2 & Chloride & $\begin{array}{c}1 \\
20\end{array}$ & $\begin{array}{c}7.96 \pm 3.19 \\
7.7 \pm 3.33\end{array}$ & $\begin{array}{l}25 \\
25\end{array}$ & $\begin{array}{l}25 \\
25\end{array}$ & $\begin{array}{l}6.34 \pm 2.75 \\
8.05 \pm 3.41\end{array}$ & $\begin{array}{l}25 \\
25\end{array}$ & $\begin{array}{l}25 \\
25\end{array}$ & 250 \\
\hline 3 & $\begin{array}{l}\text { Total hardness (as } \\
\left.\qquad \mathrm{CaCO}_{3}\right)\end{array}$ & $\begin{array}{c}1 \\
20\end{array}$ & $\begin{array}{l}14.82 \pm 8.71 \\
15.20 \pm 8.50\end{array}$ & 25 & NA & $\begin{array}{l}15.06 \pm 8.61 \\
13.73 \pm 8.75\end{array}$ & 25 & NA & NA \\
\hline 4 & Calcium (as $\mathrm{CaCO}_{3}$ ) & $\begin{array}{c}1 \\
20\end{array}$ & $\begin{array}{l}2.9 \pm 1.41 \\
3.54 \pm 1.8\end{array}$ & $\begin{array}{l}25 \\
25\end{array}$ & NA & $\begin{array}{l}3.58 \pm 1.46 \\
3.01 \pm 1.49\end{array}$ & $\begin{array}{l}25 \\
25\end{array}$ & NA & NA \\
\hline 5 & Magnesium (as $\mathrm{CaCO}_{3}$ ) & $\begin{array}{c}1 \\
20\end{array}$ & $\begin{array}{l}10.86 \pm 8.21 \\
11.86 \pm 8.45\end{array}$ & $\begin{array}{l}25 \\
25\end{array}$ & NA & $\begin{array}{l}11.18 \pm 7.6 \\
11.8 \pm 7.84\end{array}$ & $\begin{array}{l}25 \\
25\end{array}$ & NA & NA \\
\hline 6 & Iron & $\begin{array}{c}1 \\
20\end{array}$ & $\begin{array}{l}0.0037 \pm 0.002 \\
0.003 \pm 0.0011\end{array}$ & $\begin{array}{l}22 \\
22\end{array}$ & $\begin{array}{l}25 \\
25\end{array}$ & $\begin{array}{l}0.0028 \pm 0.0017 \\
0.0033 \pm 0.0017\end{array}$ & $\begin{array}{l}24 \\
23\end{array}$ & $\begin{array}{l}25 \\
25\end{array}$ & 0.3 \\
\hline 7 & Zinc & $\begin{array}{c}1 \\
20\end{array}$ & & & $\begin{array}{l}25 \\
25\end{array}$ & & & $\begin{array}{l}25 \\
25\end{array}$ & 5 \\
\hline 8 & Silver & $\begin{array}{c}1 \\
20\end{array}$ & & & NA & & & NA & 0.025 \\
\hline 9 & Copper & $\begin{array}{c}1 \\
20\end{array}$ & $\begin{array}{l}0.0084 \pm 0.0107 \\
0.0105 \pm 0.0106\end{array}$ & $\begin{array}{l}25 \\
24\end{array}$ & $\begin{array}{l}25 \\
25\end{array}$ & $\begin{array}{l}0.0073 \pm 0.0107 \\
0.0101 \pm 0.0142\end{array}$ & $\begin{array}{l}24 \\
24\end{array}$ & $\begin{array}{l}25 \\
25\end{array}$ & 1 \\
\hline 10 & Cadmium & $\begin{array}{c}1 \\
20\end{array}$ & & & $\begin{array}{l}25 \\
25\end{array}$ & & & $\begin{array}{l}25 \\
25\end{array}$ & 0.005 \\
\hline 11 & Cobalt & $\begin{array}{c}1 \\
20\end{array}$ & $\begin{array}{l}0.0283 \pm 0.0106 \\
0.0272 \pm 0.0153\end{array}$ & $\begin{array}{l}25 \\
25\end{array}$ & NA & $\begin{array}{c}0.0184 \pm 0.0119 \\
0.267 \pm 0.0106\end{array}$ & $\begin{array}{l}25 \\
25\end{array}$ & NA & NA \\
\hline 12 & Nickel & $\begin{array}{c}1 \\
20\end{array}$ & $\begin{array}{l}0.0089 \pm 0.0086 \\
0.0076 \pm 0.0079\end{array}$ & $\begin{array}{c}8 \\
10\end{array}$ & NA & $\begin{array}{l}0.0079 \pm 0.0094 \\
0.0088 \pm 0.0086\end{array}$ & $\begin{array}{l}8 \\
8\end{array}$ & NA & NA \\
\hline 13 & Lead & $\begin{array}{c}1 \\
20\end{array}$ & & & $\begin{array}{l}25 \\
25\end{array}$ & & & $\begin{array}{l}25 \\
25\end{array}$ & 0.005 \\
\hline 14 & Fluoride & $\begin{array}{c}1 \\
20\end{array}$ & $\begin{array}{c}0.047 \pm 0.01426 \\
0.046 \pm 0.0159\end{array}$ & $\begin{array}{l}25 \\
24\end{array}$ & $\begin{array}{l}25 \\
25\end{array}$ & $\begin{array}{l}0.049 \pm 0.016 \\
0.048 \pm 0.129\end{array}$ & $\begin{array}{l}25 \\
25\end{array}$ & $\begin{array}{l}25 \\
25\end{array}$ & 3 \\
\hline 15 & Sodium & $\begin{array}{c}1 \\
20\end{array}$ & $\begin{array}{l}12.36 \pm 13.35 \\
12.83 \pm 10.39\end{array}$ & $\begin{array}{l}25 \\
25\end{array}$ & NA & $\begin{array}{l}14.92 \pm 9.47 \\
10.5 \pm 10.18\end{array}$ & $\begin{array}{l}25 \\
25\end{array}$ & NA & NA \\
\hline 16 & Potassium & $\begin{array}{c}1 \\
20 \\
\end{array}$ & $\begin{array}{c}0.7 \pm 0.08 \\
2.68 \pm 3.36\end{array}$ & $\begin{array}{l}2 \\
7\end{array}$ & NA & $\begin{array}{l}0.99 \pm 0.31 \\
0.45 \pm 0.37\end{array}$ & $\begin{array}{l}5 \\
5\end{array}$ & NA & NA \\
\hline
\end{tabular}

NA: value not available in guideline; $M$ : mean; -: BDL; SD: standard deviation; $A$ : acceptability; $D$ : no. of water samples in which elements were detected.

magnesium ( $\mathrm{as}_{\mathrm{CaCo}}$ ) ranges for $1 \mathrm{~L}$ vessels in monsoon and postmonsoon seasons were found to be $0.4 \mathrm{mg} / \mathrm{L}-27.1 \mathrm{mg} / \mathrm{L}$ $(M=10.86 \mathrm{mg} / \mathrm{L}, \mathrm{SD}=8.21)$ and $0-27.1 \mathrm{mg} / \mathrm{L}(M=11.18 \mathrm{mg} / \mathrm{L}$, $\mathrm{SD}=7.6$ ), respectively. All 100 samples had magnesium (as $\mathrm{CaCO}_{3}$ ) concentration at acceptable range as per IBWA guideline. These results are presented in Table 4 and represented in Figure 7.

Levene's test for equity of variances indicated that the magnesium and seasons (monsoon and postmonsoon) demonstrated a statistically significant distribution ( $p=0.350$ at $95 \%$ confidence interval).

8.4. Residual Chlorine. All the hundred samples were subjected to titration for determination of residual chlorine. Residual chlorine was not detected and hence the samples were acceptable as per IBWA guideline. These results are presented in Table 4.

8.5. Chloride. Chloride concentration in the bottled water ranged from $2.5 \mathrm{mg} / \mathrm{L}$ to $15.9 \mathrm{mg} / \mathrm{L} \quad(M=7.51 \mathrm{mg} / \mathrm{L}$, $\mathrm{SD}=3.21)$. The chloride concentration ranges for $20 \mathrm{~L}$ water bottles in monsoon and postmonsoon seasons were found to be $2.9 \mathrm{mg} / \mathrm{L}-14.8 \mathrm{mg} / \mathrm{L} \quad(M=7.70 \mathrm{mg} / \mathrm{L}, \quad \mathrm{SD}=3.33)$ and $2.9 \mathrm{mg} / \mathrm{L}-15.9 \mathrm{mg} / \mathrm{L} \quad(M=8.05 \mathrm{mg} / \mathrm{L}, \quad \mathrm{SD}=3.41)$, respectively. The chloride concentration ranges for $1 \mathrm{~L}$ vessels in monsoon and postmonsoon seasons were found to be $4.2 \mathrm{mg} / \mathrm{L}-15.9 \mathrm{mg} / \mathrm{L}(M=7.96 \mathrm{mg} / \mathrm{L}, \mathrm{SD}=3.19)$ and $2.5 \mathrm{mg} /$ $\mathrm{L}-14.8 \mathrm{mg} / \mathrm{L}(M=6.34 \mathrm{mg} / \mathrm{L}, \mathrm{SD}=2.75)$, respectively. All 100 samples had chloride concentration at acceptable range as per IBWA guideline. These results are presented in Table 4 and represented in Figure 8.

Pearson's correlation implies that there is a significant positive association between chlorine and total hardness $(r=0.255)$, between chlorine and magnesium (as $\left.\mathrm{CaCO}_{3}\right)$ $(r=0.207)$, and between chlorine and potassium $(r=0.531)$, as seen in Table 3. Levene's test for equity of variances indicated that the chloride and seasons (monsoon and postmonsoon) demonstrated a statistically significant distribution ( $p=0.544$ at $95 \%$ confidence interval).

8.6. Iron. Iron concentration in the bottled water ranged from $0.0002 \mathrm{mg} / \mathrm{L}$ to $0.0090 \mathrm{mg} / \mathrm{L}(M=0.0032 \mathrm{mg} / \mathrm{L}, \mathrm{SD}=0.0017)$. The iron concentration ranges for $20 \mathrm{~L}$ water bottles in monsoon and postmonsoon seasons were found to be 


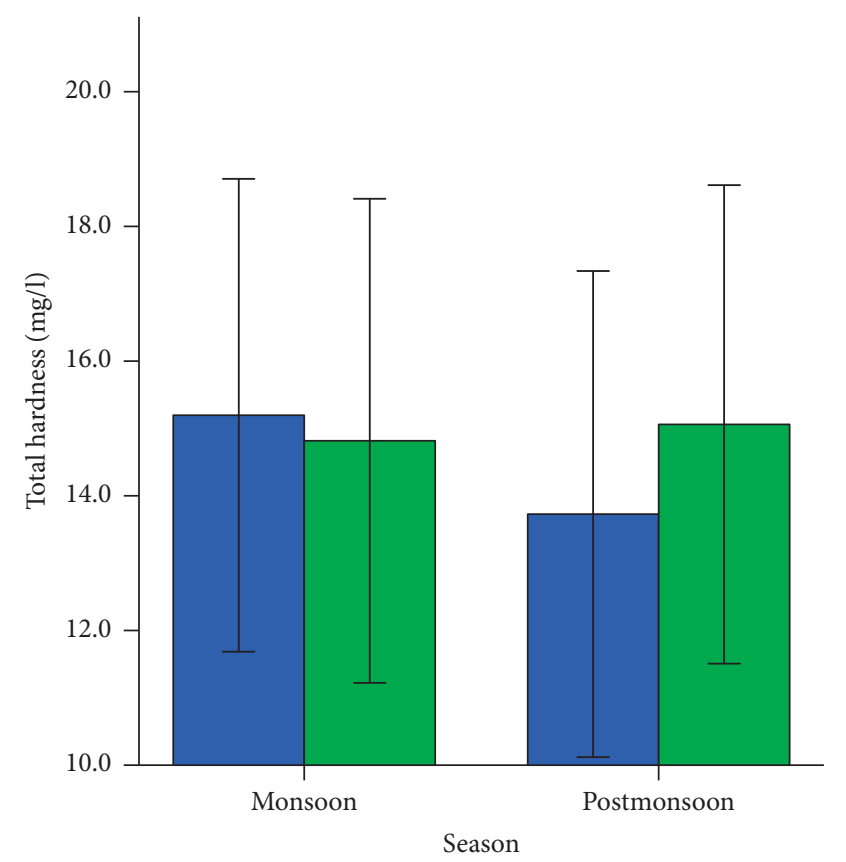

Sample from bottled water of

$$
\begin{aligned}
& \square 20 \text { liters } \\
& \square 1 \text { liter }
\end{aligned}
$$

FIgURE 5: Distribution of total hardness concentration with respect to season and bottled water.

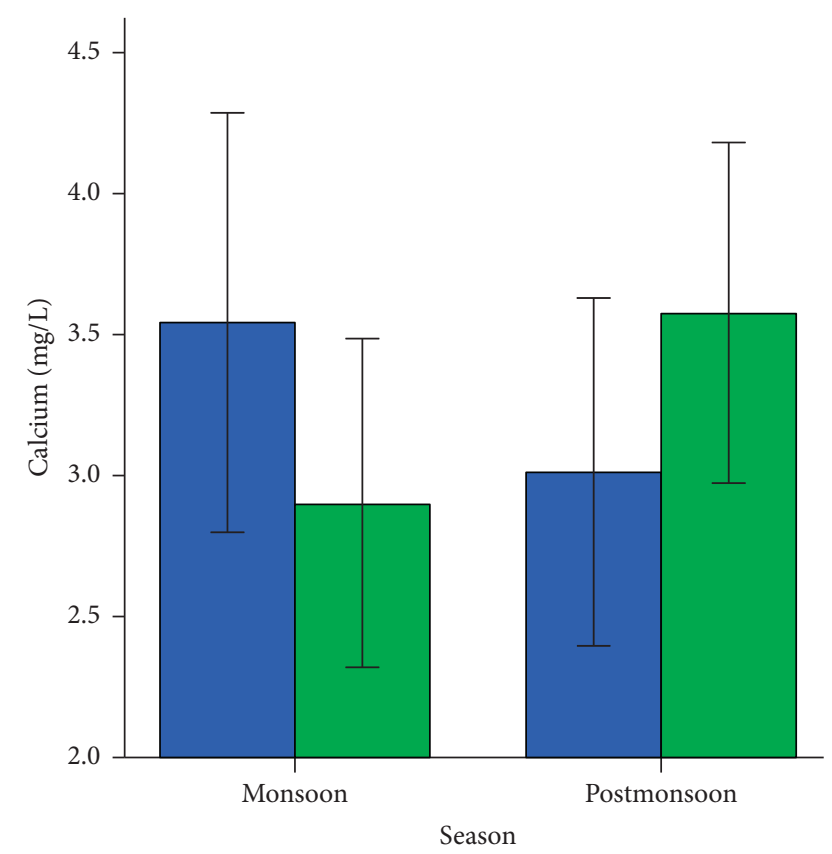

Sample from bottled water of

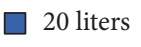

$\square 1$ liter

FIgURE 6: Distribution of calcium concentration with respect to season and bottled water.

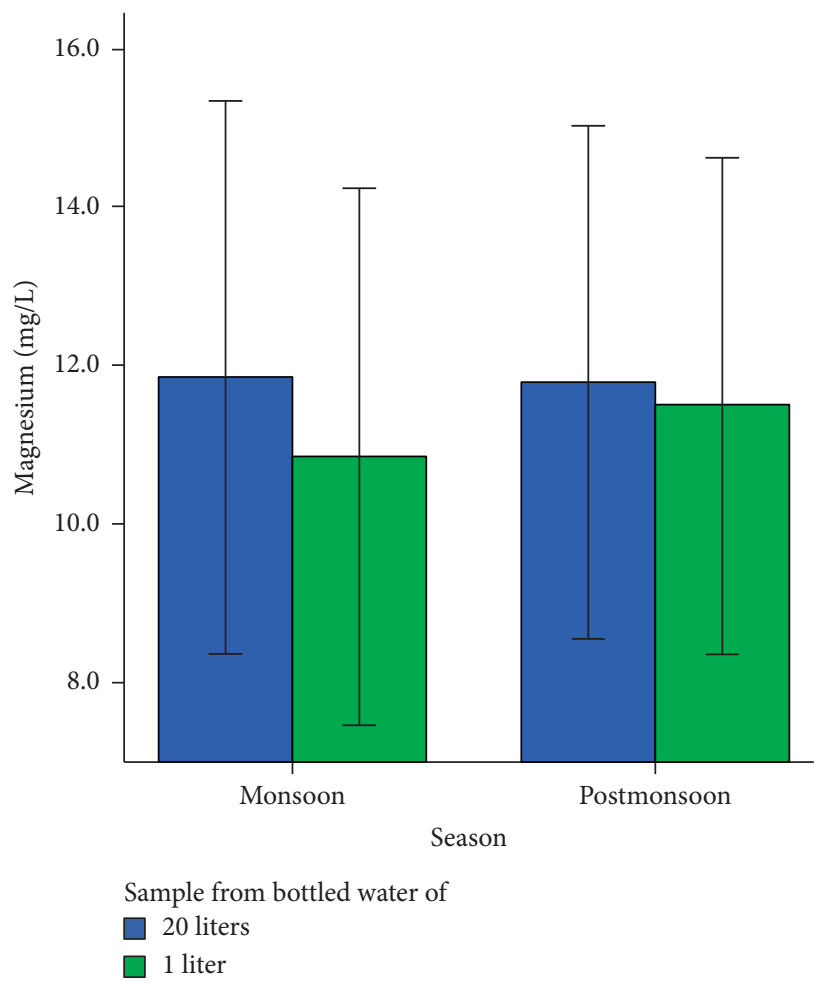

FIGURE 7: Distribution of magnesium concentration with respect to season and bottled water.

$0.0009 \mathrm{mg} / \mathrm{L}-0.0049 \mathrm{mg} / \mathrm{L}(M=0.0030 \mathrm{mg} / \mathrm{L}, \mathrm{SD}=0.0011)$ and $0.0009 \mathrm{mg} / \mathrm{L}-0.0090 \mathrm{mg} / \mathrm{L}(M=0.0033 \mathrm{mg} / \mathrm{L}, \mathrm{SD}=0.0017)$, respectively. The iron concentration ranges for $1 \mathrm{~L}$ vessels in monsoon and postmonsoon seasons were found to be $0.0018 \mathrm{mg} / \mathrm{L}-0.0090 \mathrm{mg} / \mathrm{L}(M=0.0037 \mathrm{mg} / \mathrm{L}, \mathrm{SD}=0.0020)$ and $0.0002 \mathrm{mg} / \mathrm{L}-0.0070 \mathrm{mg} / \mathrm{L}(M=0.0028 \mathrm{mg} / \mathrm{L}, \mathrm{SD}=0.0017)$, respectively. All 100 samples had iron concentration at acceptable range as per IBWA guideline. These results are presented in Table 4 and represented in Figure 9.

Pearson's correlation implies that there is a significant positive association between iron and fluoride $(r=0.280)$, as seen in Table 3. Levene's test for equity of variances indicated that the iron and seasons (monsoon and postmonsoon) demonstrated a statistically significant distribution $(p=0.693$ at $95 \%$ confidence interval).

8.7. Zinc. All the hundred samples were subjected to FAAS for determination of zinc concentration. Zinc was not detected and hence the samples were acceptable as per IBWA guideline. These results are presented in Table 4.

8.8. Silver. All the hundred samples were subjected to FAAS for determination of silver concentration. Silver was not detected and hence the samples were acceptable as per IBWA guideline. These results are presented in Table 4 . 


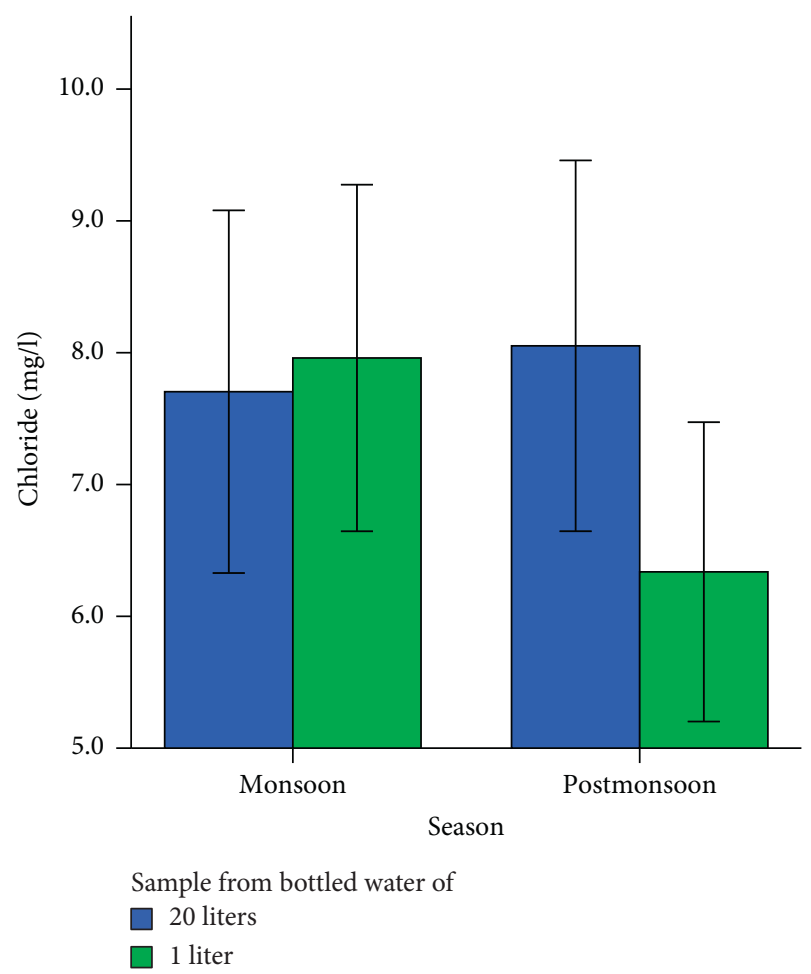

FIgURE 8: Distribution of chloride concentration with respect to season and bottled water.

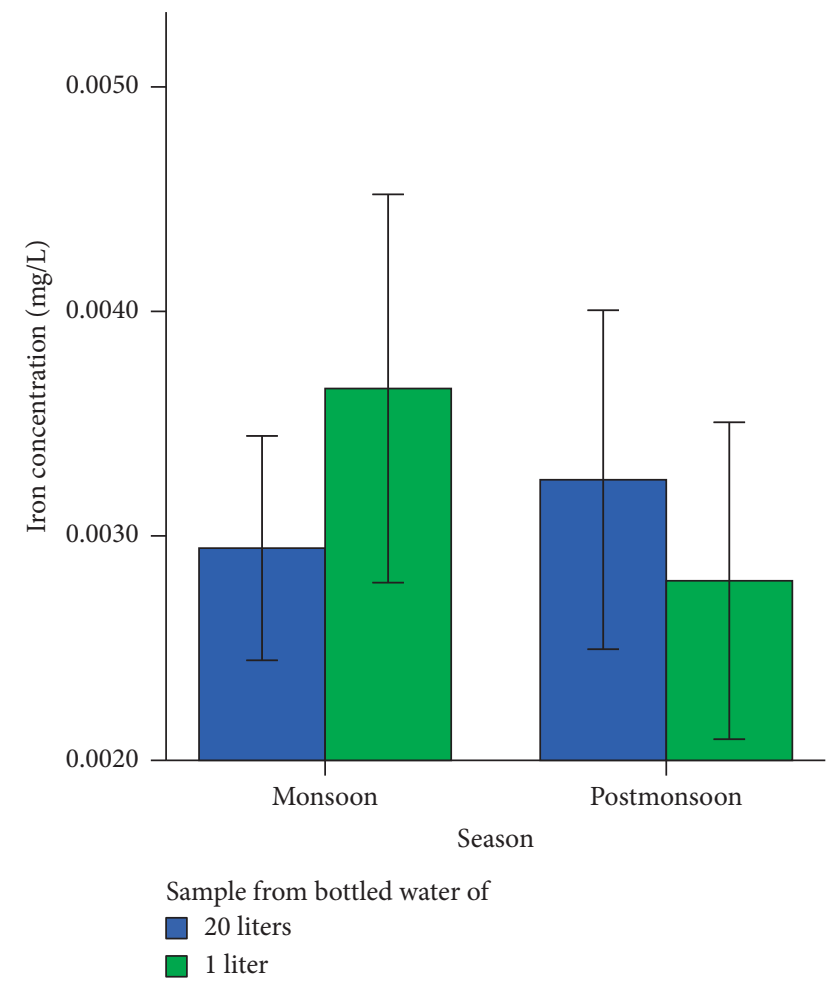

FIGURE 9: Distribution of iron concentration with respect to season and bottled water.
8.9. Copper. Copper concentration in the bottled water ranged from $0.0008 \mathrm{mg} / \mathrm{L}$ to $0.0559 \mathrm{mg} / \mathrm{L} \quad(M=0.0091 \mathrm{mg} / \mathrm{L}$, $\mathrm{SD}=0.0116)$. The copper concentration ranges for $20 \mathrm{~L}$ water bottles in monsoon and postmonsoon seasons were found to be $0.0008 \mathrm{mg} / \mathrm{L}-0.0557 \mathrm{mg} / \mathrm{L}(M=0.0105 \mathrm{mg} / \mathrm{L}, \mathrm{SD}=0.0106)$ and $0.0002 \mathrm{mg} / \mathrm{L}-0.0559 \mathrm{mg} / \mathrm{L} \quad(M=0.0101 \mathrm{mg} / \mathrm{L}, \quad \mathrm{SD}=0.0142)$, respectively. The copper concentration ranges for $1 \mathrm{~L}$ vessels in monsoon and postmonsoon seasons were found to be $0.0008 \mathrm{mg} / \mathrm{L}-0.0557 \mathrm{mg} / \mathrm{L}(M=0.0084 \mathrm{mg} / \mathrm{L}, \mathrm{SD}=0.0107)$ and $0.0005 \mathrm{mg} / \mathrm{L}-0.0557 \mathrm{mg} / \mathrm{L} \quad(M=0.0073 \mathrm{mg} / \mathrm{L}, \quad \mathrm{SD}=0.0107)$, respectively. All 100 samples had copper concentration at acceptable range as per IBWA guideline. These results are presented in Table 4 and represented in Figure 10.

Levene's test for equity of variances indicated that the copper and seasons (monsoon and postmonsoon) demonstrated a statistically significant distribution $(p=0.761$ at 95\% confidence interval).

8.10. Cadmium. All the hundred samples were subjected to FAAS for determination of cadmium concentration. Cadmium was not detected and hence the samples were acceptable as per IBWA guideline. These results are presented in Table 4.

8.11. Cobalt. Cobalt concentration in the bottled water ranged from $0.0005 \mathrm{mg} / \mathrm{L}$ to $0.0559 \mathrm{mg} / \mathrm{L}(M=0.2520 \mathrm{mg} / \mathrm{L}$, $\mathrm{SD}=0.0127)$. The cobalt concentration ranges for $20 \mathrm{~L}$ water bottles in monsoon and postmonsoon seasons were found to be $\quad 0.0120 \mathrm{mg} / \mathrm{L}-0.0524 \mathrm{mg} / \mathrm{L} \quad(M=0.0272 \mathrm{mg} / \mathrm{L}, \quad \mathrm{SD}=$ $0.0153)$ and $0.0120 \mathrm{mg} / \mathrm{L}-0.0524 \mathrm{mg} / \mathrm{L}(M=0.0267 \mathrm{mg} / \mathrm{L}$, $\mathrm{SD}=0.0106)$, respectively. The cobalt concentration ranges for $1 \mathrm{~L}$ vessels in monsoon and postmonsoon seasons were found to be $0.0142 \mathrm{mg} / \mathrm{L}-0.0524 \mathrm{mg} / \mathrm{L} \quad(M=0.0283 \mathrm{mg} / \mathrm{L}$, $\mathrm{SD}=0.0106)$ and $0.0005 \mathrm{mg} / \mathrm{L}-0.0413 \mathrm{mg} / \mathrm{L}(M=0.0184 \mathrm{mg} /$ $\mathrm{L}, \mathrm{SD}=0.0119)$, respectively. All 100 samples had cobalt concentration at acceptable range as per IBWA guideline. These results are presented in Table 4 and represented in Figure 11 .

Pearson's correlation implies that there is a significant positive association between cobalt and sodium $(r=0.212)$, as seen in Table 3. Levene's test for equity of variances indicated that the cobalt and seasons (monsoon and postmonsoon) demonstrated a statistically significant distribution ( $p=0.649$ at $95 \%$ confidence interval).

8.12. Nickel. Nickel concentration in the bottled water ranged from $0.0008 \mathrm{mg} / \mathrm{L}$ to $0.0230 \mathrm{mg} / \mathrm{L} \quad(M=0.0080 \mathrm{mg} / \mathrm{L}$, $\mathrm{SD}=0.0082)$. The nickel concentration ranges for $20 \mathrm{~L}$ water bottles in monsoon and postmonsoon seasons were found to be $0.0015 \mathrm{mg} / \mathrm{L}-0.0230 \mathrm{mg} / \mathrm{L}(M=0.0076 \mathrm{mg} / \mathrm{L}, \mathrm{SD}=0.0079)$ and $0.0017 \mathrm{mg} / \mathrm{L}-0.0230 \mathrm{mg} / \mathrm{L} \quad(M=0.0088 \mathrm{mg} / \mathrm{L}, \quad \mathrm{SD}=0.0086)$, respectively. The nickel concentration ranges for $1 \mathrm{~L}$ vessels in monsoon and postmonsoon seasons were found to be 


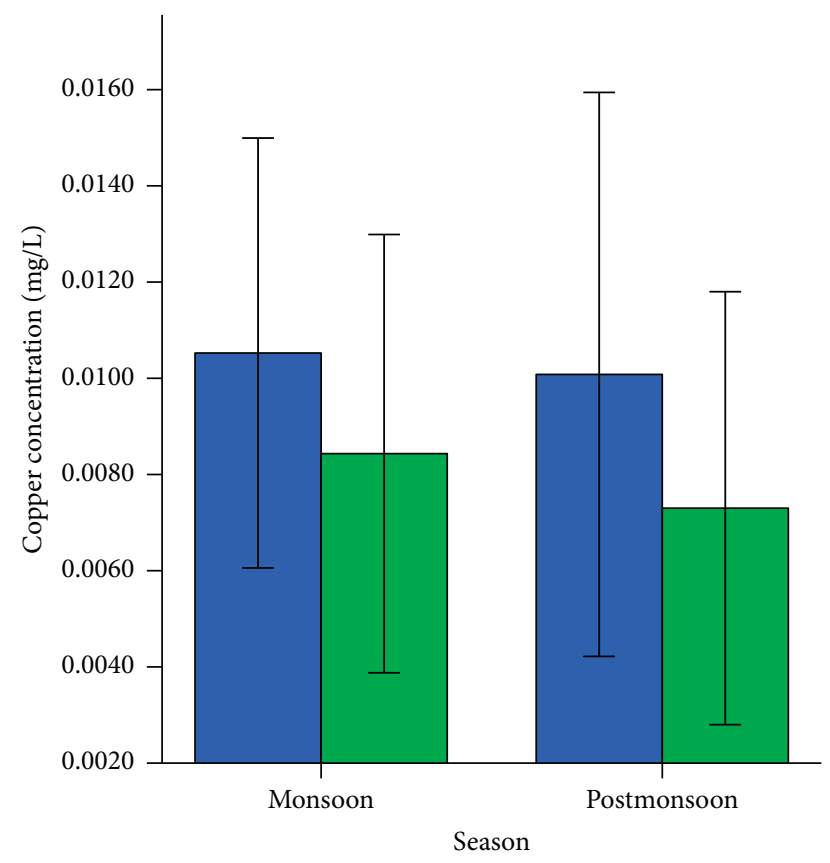

Sample from bottled water of

20 liters

$\square 1$ liter

Figure 10: Distribution of copper concentration with respect to season and bottled water.

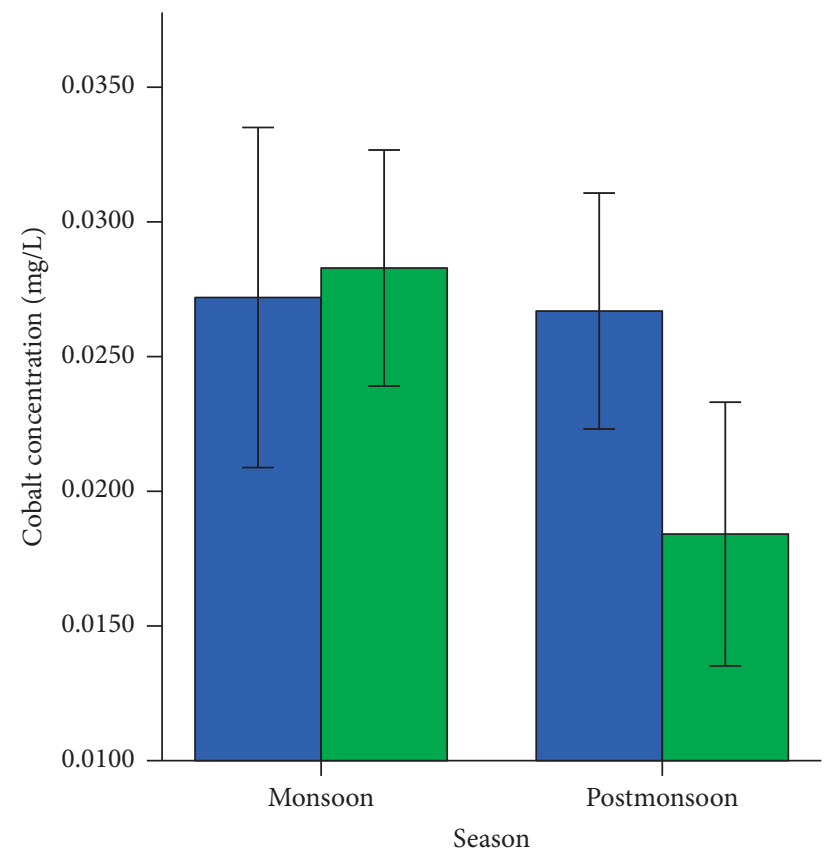

Sample from bottled water of

$\square 20$ liters

$\square 1$ liter

FIGURE 11: Distribution of cobalt concentration with respect to season and bottled water.
$0.0017 \mathrm{mg} / \mathrm{L}-0.0230 \mathrm{mg} / \mathrm{L}(M=0.0089 \mathrm{mg} / \mathrm{L}, \mathrm{SD}=0.0086)$ and $0.0008 \mathrm{mg} / \mathrm{L}-0.230 \mathrm{mg} / \mathrm{L}(M=0.0079 \mathrm{mg} / \mathrm{L}, \mathrm{SD}=0.0094)$, respectively. All 100 samples had nickel concentration at acceptable range as per IBWA guideline. These results are presented in Table 4 and represented in Figure 12.

Levene's test for equity of variances indicated that the nickel and seasons (monsoon and postmonsoon) demonstrated a statistically significant distribution $(p=0.513$ at 95\% confidence interval), as seen in Table 3.

8.13. Lead. All the hundred samples were subjected to FAAS for determination of lead concentration. Lead was not detected and hence the samples were acceptable as per IBWA guideline. These results are presented in Table 4.

8.14. Fluoride. Fluoride concentration in the bottled water ranged from $0.024 \mathrm{mg} / \mathrm{L}$ to $0.077 \mathrm{mg} / \mathrm{L} \quad(M=0.047 \mathrm{mg} / \mathrm{L}$, $\mathrm{SD}=0.0139$ ). The fluoride concentration ranges for $20 \mathrm{~L}$ water bottles in monsoon and postmonsoon seasons were found to be $0.024 \mathrm{mg} / \mathrm{L}-0.077 \mathrm{mg} / \mathrm{L} \quad(M=0.046 \mathrm{mg} / \mathrm{L}, \quad \mathrm{SD}=0.0159)$ and $0.024 \mathrm{mg} / \mathrm{L}-0.074 \mathrm{mg} / \mathrm{L} \quad(M=0.048 \mathrm{mg} / \mathrm{L}, \quad \mathrm{SD}=0.1290)$, respectively. The fluoride concentration ranges for $1 \mathrm{~L}$ vessels in monsoon and postmonsoon seasons were found to be $0.029 \mathrm{mg} / \mathrm{L}-0.068 \mathrm{mg} / \mathrm{L} \quad(M=0.047 \mathrm{mg} / \mathrm{L}, \mathrm{SD}=0.01426)$ and $0.026 \mathrm{mg} / \mathrm{L}-0.077 \mathrm{mg} / \mathrm{L}(M=0.049 \mathrm{mg} / \mathrm{L}, \mathrm{SD}=0.016)$, respectively. All 100 samples had fluoride concentration at acceptable range as per IBWA guideline. These results are presented in Table 4 and represented in Figure 13.

Levene's test for equity of variances indicated that the fluoride and seasons (monsoon and postmonsoon) demonstrated a statistically significant distribution $(p=0.792$ at 95\% confidence interval), as seen in Table 3.

8.15. Sodium. Sodium concentration in the bottled water ranged from $0.1 \mathrm{mg} / \mathrm{L}$ to $54.0 \mathrm{mg} / \mathrm{L} \quad(M=12.65 \mathrm{mg} / \mathrm{L}$, $\mathrm{SD}=10.90)$. The sodium concentration ranges for $20 \mathrm{~L}$ water bottles in monsoon and postmonsoon seasons were found to be $0.1 \mathrm{mg} / \mathrm{L}-29.7 \mathrm{mg} / \mathrm{L}(M=12.83 \mathrm{mg} / \mathrm{L}, \mathrm{SD}=10.39)$ and $0.6 \mathrm{mg} / \mathrm{L}-36.7 \mathrm{mg} / \mathrm{L}(M=10.50 \mathrm{mg} / \mathrm{L}, \mathrm{SD}=10.18)$, respectively. The sodium concentration ranges for $1 \mathrm{~L}$ vessels in monsoon and postmonsoon seasons were found to be $0.6 \mathrm{mg} / \mathrm{L}-54.0 \mathrm{mg} / \mathrm{L} \quad(M=12.36 \mathrm{mg} / \mathrm{L}, \quad \mathrm{SD}=13.35) \quad$ and $0.6 \mathrm{mg} / \mathrm{L}-30.1 \mathrm{mg} / \mathrm{L} \quad(M=14.92 \mathrm{mg} / \mathrm{L}, \quad \mathrm{SD}=9.47)$, respectively. All 100 samples had sodium concentration at acceptable range as per IBWA guideline. These results are presented in Table 4 and represented in Figure 14.

Pearson's correlation implies that there is a significant positive association between sodium and potassium $(r=0.458)$, as seen in Table 3. Levene's test for equity of variances indicated that the sodium and seasons (premonsoon and postmonsoon) demonstrated a statistically significant distribution $(p=0.426$ at $95 \%$ confidence interval). 


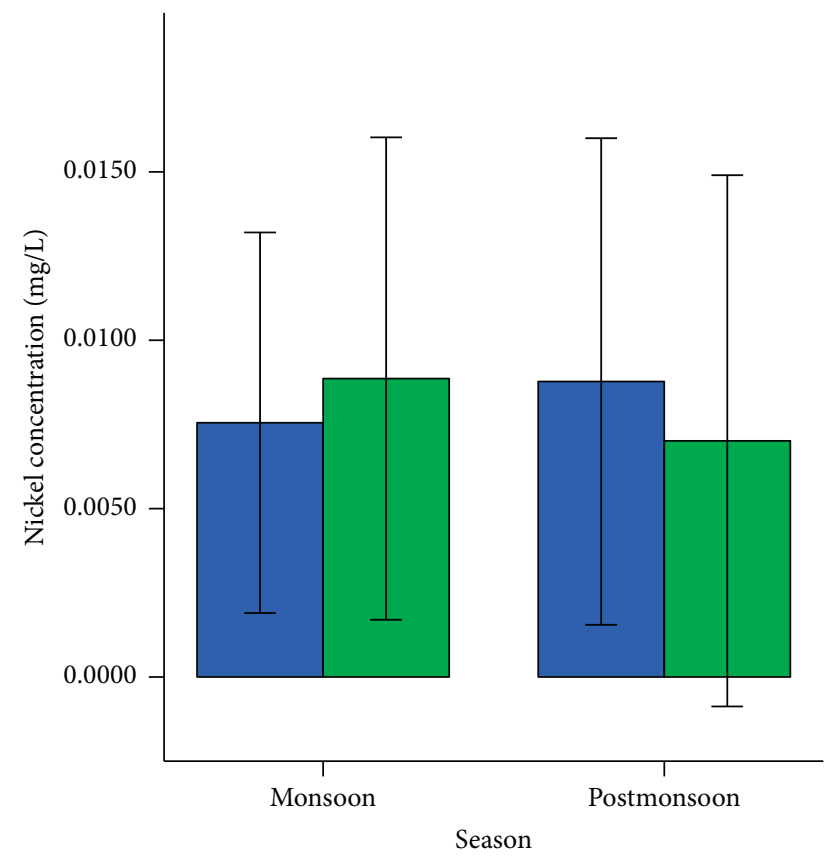

Sample from bottled water of

$\square 20$ liters

$\square 1$ liter

FIGURE 12: Distribution of nickel concentration with respect to season and bottled water.

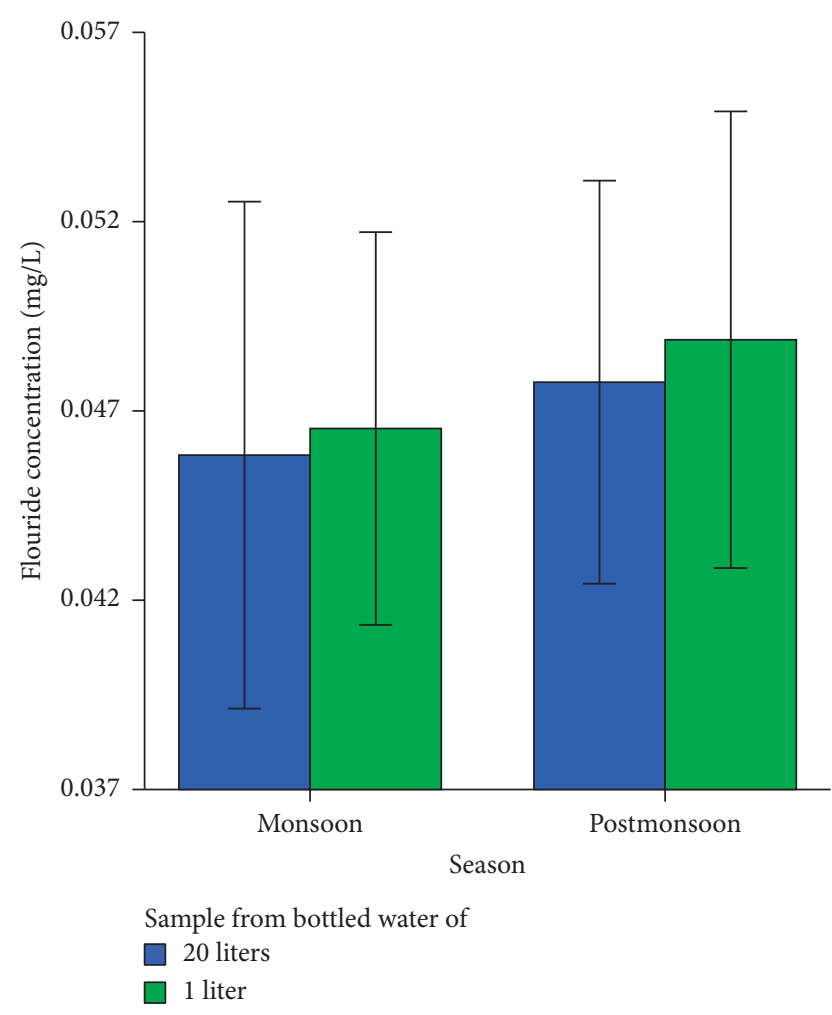

FIGURE 13: Distribution of fluoride concentration with respect to season and bottled water.

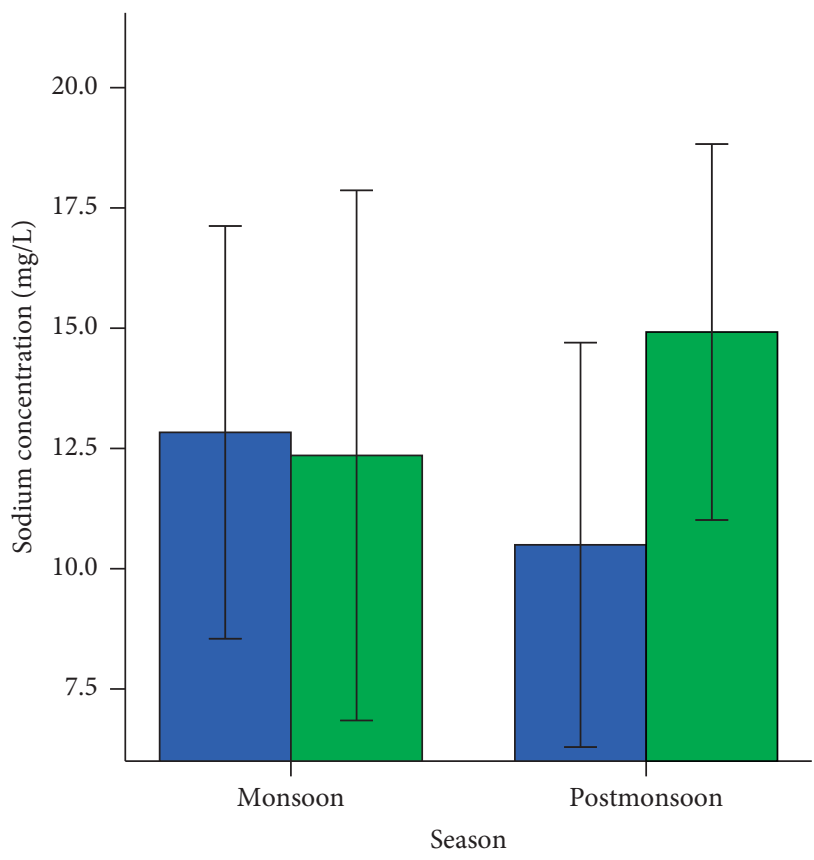

Sample from bottled water of $\square 20$ liters

$\square 1$ liter

FIGURE 14: Distribution of sodium concentration with respect to season and bottled water.

8.16. Potassium. Potassium concentration in the bottled water ranged from $0.2 \mathrm{mg} / \mathrm{L}$ to $9.0 \mathrm{mg} / \mathrm{L}(M=1.41 \mathrm{mg} / \mathrm{L}$, $\mathrm{SD}=2.00)$. The potassium concentration ranges for $20 \mathrm{~L}$ water bottles in monsoon and postmonsoon seasons were found to be $0.5 \mathrm{mg} / \mathrm{L}-9.0 \mathrm{mg} / \mathrm{L}(M=2.68 \mathrm{mg} / \mathrm{L}, \mathrm{SD}=3.36)$ and $0.2 \mathrm{mg} / \mathrm{L}-0.7 \mathrm{mg} / \mathrm{L}(M=0.45 \mathrm{mg} / \mathrm{L}, \mathrm{SD}=0.37)$, respectively. The potassium concentration ranges for $1 \mathrm{~L}$ vessels in monsoon and postmonsoon seasons were found to be $0.6 \mathrm{mg} / \mathrm{L}-0.8 \mathrm{mg} / \mathrm{L}(M=0.7 \mathrm{mg} / \mathrm{L}, \mathrm{SD}=0.08)$ and $0.6 \mathrm{mg} /$ $\mathrm{L}-1.4 \mathrm{mg} / \mathrm{L}(M=0.99 \mathrm{mg} / \mathrm{L}, \mathrm{SD}=0.31)$, respectively. All 100 samples had potassium concentration at acceptable range as per IBWA guideline. These results are presented in Table 4 and represented in Figure 15.

Levene's test for equity of variances indicated that the potassium and seasons (premonsoon and postmonsoon) demonstrated a statistically significant distribution ( $p=0.086$ at $95 \%$ confidence interval).

\section{Discussion}

The $\mathrm{pH}$ value of water samples tested ranged from 5.2 to 8.2. Low $\mathrm{pH}$ values observed in most samples could be associated with $\mathrm{CO}_{2}$ saturation in the groundwater, which might be a common source for these industries [16]. Studies $[8,9,14,17]$ have found the link between low $\mathrm{pH}$ and peptic ulcer [18], gastroesophageal reflux disease [19, 20], low absorption of vitamins [21], and so forth. However, $\mathrm{pH}$ 


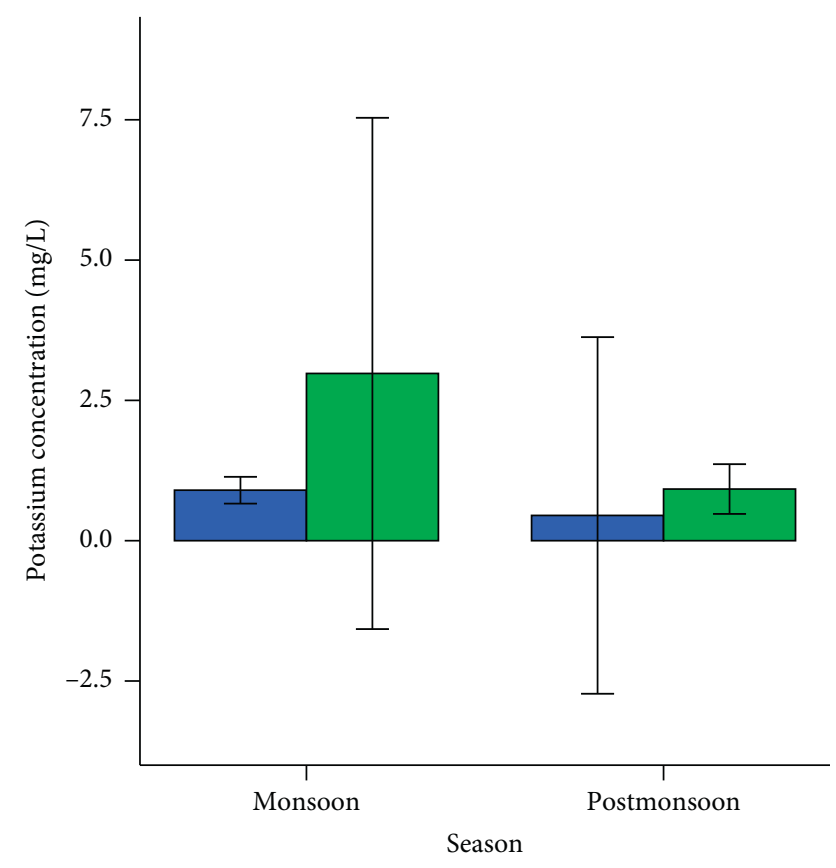

Sample from bottled water of $\square 20$ liters

$\square 1$ liter

FIGURE 15: Distribution of potassium concentration with respect to season and bottled water.

values of drinking water below 6.5 are not harmful for direct consumption from bottled water but are known to cause corrosion to metal pipes which may lead to elevated level of copper, lead, zinc, iron, and so forth in tap water [7].

The value of electrical conductivity (EC) was found to range from 5 to $199 \mu \mathrm{S} / \mathrm{cm}$. All the samples were within the acceptable limit and in agreement with studies carried out by Aris et al. [22], Danso-Boateng and Frimpong [16], Mihayo and Mkoma [23], and Sasikaran et al. [24], where electrical conductivity was found to be between 2 and $192 \mu \mathrm{S} / \mathrm{cm}$, 5.93-93.2 $\mu \mathrm{S} / \mathrm{cm}, 17.4-280 \mu \mathrm{S} / \mathrm{cm}$, and $19-253 \mu \mathrm{S} / \mathrm{cm}$, respectively, as presented in Table 5. Lower EC values indicate low ionic concentration and higher EC values indicate higher ionic concentration. Lower EC values in bottled water might harm health of consumers [7].

Total dissolved solid (TDS) was found to be in the range of $1-15 \mathrm{mg} / \mathrm{L}$. TDS is used to assess mineral content and is dependent on water source, local geology, and treatment scheme [26]. TDS is a measure of the cations and anions, and water close to 0 TDS has a flat taste [15].

Turbidity values of the bottled water were found to be in the range of $0.2-1.55 \mathrm{NTU}$, which is within IBWA guideline values and in agreement with the study carried out by Farhadkhani et al. [27] whose range was 0.15-2.47 NTU. This implies that bottled water had low levels of particulate and organic matter. The main reason for this could be the effective processing and filtering system in bottled-water companies [28]. High turbidity is often associated with pathogens, including viruses, bacteria, and other parasites [29].
The range of total hardness was found to be $0.8-31 \mathrm{mg} / \mathrm{L}$. Consumption of soft water $(<50 \mathrm{mg} / \mathrm{L})$ lacking essential minerals (like calcium, magnesium, and other trace minerals) is harmful to the body as water low in mineral content could potentially result in depletion of the body's minerals [11]. People drinking such treated water excrete huge amount of calcium, magnesium, and other trace minerals in their urine [7]. The more the mineral loss, the greater the risk for osteoporosis, osteoarthritis, hypothyroidism, coronary artery disease, high blood pressure, and a long list of degenerative diseases generally associated with premature ageing [30]. Likewise, cooking food in soft water pulls the minerals out of them and lowers their natural value [31].

The calcium hardness in this study was found to be in the range of $0.4-6.2 \mathrm{mg} / \mathrm{L}$, which is in agreement with results from Danso-Boateng and Frimpong [16]. Deficiency in calcium has been associated with a decrease in blood clotting factors [32]. Calcium is the most abundant mineral in the body; it makes up about $1.5 \%$ to $2 \%$ of the body weight and $39 \%$ of the total body minerals [30]. Approximately 99\% of the calcium exists in the bones and teeth [32]. It is vital to every cell of the body for muscle contraction, nerve impulses, blood clotting, and many other uses [30]. A lack of calcium can cause osteoporosis (a disease in which the bones become extremely porous) [32]. A metabolite of vitamin $D$ 1,25-dihydroxycholecalciferol is produced by kidney, which aids in calcium absorption in upper small intestine [30]. About $10 \mathrm{gm}$ of calcium is filtered in 24 hours by the renal glomeruli [32]. Excretion through feces is more common in the human body but calcium is also excreted through sweat [30].

The value of magnesium hardness was found to be in the range of $0.2 \mathrm{mg} / \mathrm{L}-28.0 \mathrm{mg} / \mathrm{L}$. The result of this study was in agreement with Saleh et al. [33]. It is found in certain enzyme like cocarboxylase [32]. Its absorption is increased by the parathyroid hormone [30]. Normal concentration of magnesium in blood is $1.7-2.6 \mathrm{mg} / 100 \mathrm{~mL}$. It is also present in cerebrospinal fluid and muscle [32].

Residual chlorine was below detection limit in all 100 samples. Chlorine is a powerful disinfectant that is mainly used for its residual effect. Residual chlorine has the potential to kill bacteria, some parasites, and algae and also inhibits the formation of biofilms [7, 11]. Its physiological functions are that it aids in amylase activation and production of hydrochloric acid in gastric juice [30]. In water at acidic $\mathrm{pH}$ and at room temperature, chlorine reacts to form hypochlorous acid and hypochlorite, which has antimicrobial property $[7,11]$.

The range of chloride concentration of bottled water, 2.5-15.9 mg/L, was found to be within IBWA guideline value, that is, $250 \mathrm{mg} / \mathrm{L}$. The finding of the study agreed with the studies of Alsulaili et al. [34], Mihayo and Mkoma [23], Mohsin et al. [35], and Singla et al. [25] who obtained their result in the ranges of $1.24-16.9 \mathrm{mg} / \mathrm{L}, 5.97-28.78 \mathrm{mg} / \mathrm{L}, 2.5-48.2 \mathrm{mg} / \mathrm{L}$, $16-66 \mathrm{mg} / \mathrm{L}$, and $12.4-28.5 \mathrm{mg} / \mathrm{L}$, respectively, as presented in Table 5. Chloride can be an indicator of human pollution (sewage, industrial effluents, urban runoffs, etc.) or natural pollution due to geographical location $[5,7]$. In tropical countries, addition of $\mathrm{NaCl}$ in the diet is of great importance, as $\mathrm{NaCl}$ is lost in the form of sweat [30]. 
TABLE 5: Comparison of trace elements with IBWA guidelines with those of different authors.

\begin{tabular}{|c|c|c|c|c|c|c|c|}
\hline \multirow[b]{2}{*}{ Sn } & \multirow[b]{2}{*}{ Micronutrient } & \multirow{2}{*}{$\begin{array}{c}\text { IBWA } \\
\text { guidelines }\end{array}$} & \multicolumn{5}{|c|}{$M \pm \mathrm{SD}$} \\
\hline & & & Current study & $\begin{array}{c}\text { Krachler and } \\
\text { Shotyk [12] (Md) }\end{array}$ & Aris et al. [22] & $\begin{array}{l}\text { Mihayo and } \\
\text { Mkoma [23] }\end{array}$ & $\begin{array}{c}\text { Singla et al. } \\
{[25]}\end{array}$ \\
\hline 1 & $\mathrm{pH}$ & $6.5-8.5^{*}$ & $5.96 \pm 0.54$ & $\mathrm{X}$ & $7.329 \pm 0.26$ & $7.4 \pm 0.1$ & $6.93 \pm 0.023$ \\
\hline 2 & $\begin{array}{l}\text { Electrical conductivity } \\
(\mu \mathrm{S} / \mathrm{cm})\end{array}$ & NA & $59.97 \pm 58.65$ & $\mathrm{X}$ & $0.239 \pm 0.066$ & $170.1 \pm 111.5$ & $\mathrm{X}$ \\
\hline 3 & $\begin{array}{l}\text { Total dissolved solids } \\
\text { (ppm) }\end{array}$ & 500 & $4.42 \pm 3.69$ & $\mathrm{X}$ & $167.20 \pm 44.93$ & $76.6 \pm 50.2$ & $59.75 \pm 53.34$ \\
\hline 4 & Turbidity (NTU) & 0.5 & $0.408 \pm 0.195$ & $\mathrm{X}$ & $\mathrm{X}$ & $0.5 \pm 0.5$ & $\mathrm{X}$ \\
\hline 5 & $\begin{array}{l}\text { Residual chlorine } \\
\text { (ppm) }\end{array}$ & 0.1 & BDL & $\mathrm{X}$ & $\mathrm{X}$ & $\mathrm{X}$ & $\mathrm{X}$ \\
\hline 6 & Chloride (ppm) & 250 & $7.51 \pm 3.21$ & $\mathrm{X}$ & $\mathrm{X}$ & $17.2 \pm 16.9$ & $17.08 \pm 4.58$ \\
\hline 7 & $\begin{array}{l}\text { Total hardness (as } \\
\left.\mathrm{CaCO}_{3}\right)(\mathrm{ppm})\end{array}$ & NA & $14.78 \pm 8.43$ & $\mathrm{X}$ & $\mathrm{X}$ & $37.6 \pm 17.6$ & $22.49 \pm 34.74$ \\
\hline 8 & $\begin{array}{c}\left.\text { Calcium (as } \mathrm{CaCO}_{3}\right) \\
(\mathrm{ppm})\end{array}$ & NA & $3.26 \pm 1.55$ & 62.8 & $\mathrm{X}$ & $9.1 \pm 3.7$ & $8.33 \pm 12.98$ \\
\hline 9 & $\begin{array}{l}\text { Magnesium (as } \\
\left.\mathrm{CaCO}_{3}\right) \text { (ppm) }\end{array}$ & NA & $11.51 \pm 7.92$ & 13.4 & $\mathrm{X}$ & $3.6 \pm 3.0$ & $0.356 \pm 0.625$ \\
\hline 10 & Iron $(\mathrm{ppm})$ & 0.3 & $0.0032 \pm 0.0017$ & 0.75 & $\mathrm{X}$ & $0.02 \pm 0.01$ & $0.010 \pm 0.375$ \\
\hline 11 & Zinc (ppm) & 5 & BDL & 0.64 & $11.55 \pm 13.11$ & $\mathrm{X}$ & $0.005 \pm 0.007$ \\
\hline 12 & Silver (ppm) & 0.025 & BDL & $\mathrm{X}$ & $\mathrm{X}$ & $\mathrm{X}$ & $\mathrm{X}$ \\
\hline 13 & Copper (ppm) & 1 & $0.0091 \pm 0.0116$ & 0.17 & $0.64 \pm 0.53$ & $\mathrm{X}$ & $0.746 \pm 0.022$ \\
\hline 14 & Cadmium (ppm) & 0.005 & BDL & 0.008 & $\mathrm{X}$ & $\mathrm{X}$ & $\mathrm{X}$ \\
\hline 15 & Cobalt (ppm) & NA & $0.2520 \pm 0.0127$ & 0.024 & $\mathrm{X}$ & $\mathrm{X}$ & $\mathrm{X}$ \\
\hline 16 & Nickel (ppm) & NA & $0.0080 \pm 0.0082$ & $\mathrm{X}$ & $\mathrm{X}$ & $\mathrm{X}$ & $\mathrm{X}$ \\
\hline 17 & Lead (ppm) & 0.005 & $\mathrm{BDL}$ & 0.009 & $\mathrm{X}$ & $\mathrm{X}$ & $0.009 \pm 0.016$ \\
\hline 18 & Fluoride (ppm) & 3 & $0.047 \pm 0.0139$ & $\mathrm{X}$ & $\mathrm{X}$ & $\mathrm{X}$ & $0.079 \pm 0.082$ \\
\hline 19 & Sodium (ppm) & NA & $12.65 \pm 10.90$ & 0.17 & $22431.00 \pm 29514.15$ & $\mathrm{X}$ & $3.478 \pm 2.070$ \\
\hline 20 & Potassium (ppm) & NA & $1.41 \pm 2.00$ & $\mathrm{X}$ & $2845.00 \pm 2252.58$ & $\mathrm{X}$ & $4.99 \pm 1.243$ \\
\hline
\end{tabular}

* Not enforceable; NA: value not available in guideline; $X$ : not assessed by the author; $M \pm$ SD: mean \pm standard deviation; BDL: below detection limit; Md: median.

Iron concentration in this study was found to be in the range of $0.0002 \mathrm{mg} / \mathrm{L}-0.0090 \mathrm{mg} / \mathrm{L}$. The results of this study agree with the results of Singla et al. [25], where iron concentration was in the range of BDL- $0.040 \mathrm{mg} / \mathrm{L}$, as presented in Table 5. Iron is an essential component of hemoglobin, myoglobin, cytochromes, cytochrome oxidase, catalase, and peroxidase [30]. Higher concentration of iron gives bitter taste, metallic taste, and stains clothes and promotes growth of iron-metabolizing bacteria [15].

Zinc was below detection limit in all 100 samples. The result of this study agreed with the result of Singla et al. [25], where zinc concentration was in the range of BDL- $0.015 \mathrm{mg} /$ $\mathrm{L}$, as presented in Table 5 . Zinc is present in many enzymes such as carbonic anhydrase, alkaline phosphatase, pancreatic carboxylase peptides, cytosolic superoxide dismutase, and retinene reductase (aids in forming retina) [36].

Copper was found to be in the range of $0.0008 \mathrm{mg} /$ $\mathrm{L}-0.0559 \mathrm{mg} / \mathrm{L}$. The results of this study agree with the results of Singla et al. [25], where copper concentration was in the range of $0.034-0.98 \mathrm{mg} / \mathrm{L}$, as presented in Table 5 . Some of its important physiological functions are hemoglobin synthesis, melanin formation, phospholipid synthesis, collagen synthesis, and maintaining integrity of myelin sheath [30].

Cadmium was below detection limit in all 100 samples. Long-term exposure to lower levels leads to a build-up in the kidneys and possible kidney disease, lung damage, and fragile bones [37]. In a study conducted by Menke et al. [38], metals (barium, cadmium, cobalt, cesium, molybdenum, lead, antimony, thallium, tungsten, and uranium) were positively associated with diabetes, where metals catalyzed oxidative stress reactions and the resulting oxidative stress may decrease insulin gene promoter activity and insulin mRNA expression in islet's $\beta$ cells [36].

Cobalt was found to be in the range of $0.0005 \mathrm{mg} /$ $\mathrm{L}-0.0559 \mathrm{mg} / \mathrm{L}$. Cobalt is an essential micronutrient as it forms part of vitamin $B_{12}$ (necessary for normal erythrocyte formation) [30].

Nickel was found to be in the range of BDL- $0.0230 \mathrm{mg} /$ L. Nickel can substitute calcium in physiological functions like nerve transmission and muscle contraction [39]. Nickel exists in human serum as nickel bound to ultrafilterable ligands, albumin-bound nickel, and macroglobulin-bound nickel [40]. Nickel is present in RNA and is also found to be bound to proteins (keratin and insulin), amino acids, and serum albumins and has been found to be involved in the transmission of genetic code (DNA and RNA) and it is also present in certain enzyme systems that metabolize sugars [41]. It also activates enzymes like arginase, trypsin, and acetyl coenzyme A and regulates blood pressure control, sperm physiology, sodium metabolism, and cardiovascular health [40].

Lead was below detection limit in all 100 samples. The result of this study agrees with the results of Singla et al. [25], 
where lead concentration was in the range of BDL-0.058 mg/L, as presented in Table 5. Lead is not an essential component of our body but is always present in our body due to easy absorption by our body in various forms [30].

Silver was below detection limit in all 100 samples. It shows antimicrobial activity (disinfectant property) only above $50 \mu \mathrm{g} / \mathrm{l}$ in water [7]. Toxic effect of silver in human is argyria (skin and hair are heavily discolored) in the tissues [7]. Hair and nail growth provides a route for the excretion of silver from the human body, but most will be eliminated via the liver and kidneys [42]. Silver nitrate (recently claimed to be superior to many antibiotics) has been effective in inhibiting $P$. aeruginosa but can cause leakage of cellular electrolytes including sodium and potassium [43].

Fluoride concentration in bottled water was found to be in the range of BDL- $0.077 \mathrm{mg} / \mathrm{L}$. The results of this study are in agreement with Singla et al. [25], where the average value of fluoride was found to be $0.014-0.25 \mathrm{mg} / \mathrm{L}$, as presented in Table 5. Bottled water may not provide sufficient fluoride to maintain optimal dental, kidney, and skeletal health and most bottled water contains low concentration fluoride [44]. It is widely used in combination with vitamin $D$ for treatment of osteoporosis [30]. Some abnormalities due to excessive amount of fluoride are dental fluorosis (molten enamel), hypercalcification of bones, neurological disturbances, and so forth [30].

Sodium concentration in bottled water was found to be in the range of $0.1 \mathrm{mg} / \mathrm{L}-54.0 \mathrm{mg} / \mathrm{L}$. The results of this study are in agreement with those of Aris et al. [22] who determined the values of sodium chloride in the range of 1.1-65.1 mg/L, as presented in Table 5. Presence of sodium concentration in bottled water might be due to treatment of reverse osmosis followed by addition of sodium carbonate and sodium bicarbonate. It plays an important role in developing high blood pressure [33]. It is also involved in initiating and maintaining the heart beat and in absorption of glucose, galactose, and amino acid from small intestine [30]. In diarrheal patients, it is lost in large amount; as a result, there is imbalance in electrolytes which may lead to morbidity [32]. Persons suffering from hypertension should not take more than $1 \mathrm{gm}$ of sodium [30].

Potassium concentration in bottled water was found to be in the range BDL- $9.0 \mathrm{mg} / \mathrm{L}$. The result of this study was consistent with studies carried out by Aris et al. [22], Saleh et al. [33], and Singla et al. [25], where estimated potassium concentrations were $1.32-4.44 \mathrm{mg} / \mathrm{L}$, $\mathrm{BDL}-7.5 \mathrm{mg} / \mathrm{L}$, and $1.21-6.51 \mathrm{mg} / \mathrm{L}$, respectively, as presented in Table 5 . Along with $\mathrm{Na}$ and $\mathrm{K}$, it aids in acid-base balance and osmotic pressure [32]. It is essential for protein biosynthesis by ribosomes and is required by enzymes like pyruvate kinase [30]. Erythrocytes also contain large amount of potassium [32]. When in high concentration in bottled water, it may lead to renal disorders and other health concerns [30, 32].

Water is a universal solvent as it has the capacity to dissolve many elements in ionic form. Bottled water contains minerals and ions beneficial to human life, which aid in electrolyte balance, and they are also required for formation of enzymes and hormone. As these chemicals detected in the bottled water are surplus for continued existence for a short period of time (e.g., fasting), these chemicals in bottled water must also be enough to aid the survival of microorganisms [45].

\section{Conclusions}

Water could have percolated down from the surface to the ground and as such the difference in concentration of trace elements in premonsoon and postmonsoon seasons could be noticeable. After assessing the trace elements, it has been found that the trace elements detected in the bottled water were within the permissible limit of IBWA guidelines. There are many trace elements, which are not taken into consideration especially by Department of Food Technology and Quality Control (DFTQC), IBWA, Food and Drug Administration (FDA), and World Health Association (WHO) in the present guidelines. The role of trace elements in survival of microorganisms in bottled water could lead to a new wide door to epigenetics and metagenomics.

\section{Data Availability}

Data are included within the article and are also available upon request to the corresponding author.

\section{Conflicts of Interest}

The author declares that there are no conflicts of interest.

\section{Authors' Contributions}

Bikram Gautam developed the methodology, acquired PG health research grant 2017 (Grant no. 486/2017), and conducted the study.

\section{Acknowledgments}

The author acknowledges Nepal Research Health Council, Ministry of Health and Population, Government of Nepal, for providing grant for this study. The author would also like to acknowledge Department of Mines and Geology, Ministry of Industry; Department of Microbiology, St. Xavier's College; and Research Center for Applied Science and Technology for their collaboration. The author is also thankful to Professor Dr. Rameshwar Adhikari, Professor Dr. David Ussery, Dr. Ishwor Subedi, Professor Dr. Deena Bajracharya, Mr. Prakash Manandhar, Mr. Rajendra Prasad Khanal, Dr. Sijan Thapa, Dr. Lomas Aryal, Dr. Bishwanath Acharya, Mrs. Pramila Parajuli, Mr. Anup Basnet, Mr. Kanchan Thapa, Mrs. Prashamsha Pant, and Mr. Manoj Rana for their valuable suggestions. The funding for this study was provided by Nepal Health Research Council, Ministry of Health and Population, Nepal. 


\section{References}

[1] DFTQC, Nepalese Mandatory Food and Feed Standards, Department of Food Technology and Quality Control, Ministry of agricultural development, Babarmahal, Kathmandu, 2016.

[2] IBWA, Bottled Water Code of Practice, International Bottled Water Association, Alexandria, Egypt, 2012.

[3] C. Güler, "Evaluation of maximum contaminant levels in Turkish bottled drinking waters utilizing parameters reported on manufacturer's labeling and government-issued production licenses," Journal of Food Composition and Analysis, vol. 20, no. 3-4, pp. 262-272, 2007.

[4] B. Gautam and R. Adhikari, "Association of antibiotic and heavy metal resistant bacteria screened from wastewater," International Journal of Environment, vol. 7, no. 1, pp. 28-40, 2018.

[5] B. Gautam, L. Aryal, S. Adhikari et al., "Isolation of bacteriophage from Guheswori sewage treatment plant capable of infecting pathogens," Research in Pharmacy and Health Sciences, vol. 4, no. 2, pp. 465-470, 2018.

[6] B. Gautam, A. Rajbhanshi, and R. Adhikari, "Bacterial load reduction in Guheswori Sewage treatment plant, Kathmandu, Nepal," Journal of College of Medical Sciences-Nepal, vol. 15, no. 1, pp. 40-44, 2019.

[7] WHO, Guidelines for Drinking Water Quality, World Health Organisation, Geneva, Switzerland, 2017.

[8] B. Gautam, E. Dongol, and A. Shrestha, "In-vitro antimicrobial activity of different toothpastes," Journal of Kathmandu Medical College, vol. 13, pp. 52-58, 2017.

[9] B. Gautam, R. Nepal, R. Bhandari, and S. Gyawali, "Evaluation of ginger extract's yield, using cold extraction method and its antimicrobial activity against pathogens," Asian Journal of Medical and Biological Research, vol. 5, no. 1, pp. 8-13, 2019.

[10] O. Naidenko, N. Leiba, R. Sharp, and J. Houlihan, "Bottled water quality investigation: 10 major brands, 38 pollutants," vol. 5, no. 10, pp. 178-184, Environmental Working Group, 2008.

[11] WHO, Nutrients in Drinking Water, World Health Organisation, Geneva, Switzerland, 2005.

[12] M. Krachler and W. Shotyk, "Trace and ultratrace metals in bottled waters: survey of sources worldwide and comparison with refillable metal bottles," Science of the Total Environment, vol. 407, no. 3, pp. 1089-1096, 2009.

[13] A. Ikem, S. Odueyungbo, N. O. Egiebor, and K. Nyavor, "Chemical quality of bottled waters from three cities in eastern Alabama," Science of the Total Environment, vol. 285, no. 1-3, pp. 165-175, 2002.

[14] B. Gautam, S. Pokhrel, S. Aryal, and A. Basnet, "Efficacy of toothpaste in reducing micro-flora isolated from toothbrush," Kathmandu University Journal of Science, Engineering and Technology, vol. 13, pp. 71-78, 2017b.

[15] APHA, Standard Method for the Examination of Water and Wastewater, American Public Health Association, Washington, DC, USA, 2005.

[16] E. Danso-Boateng and I. K. Frimpong, "Quality analysis of plastic sachet and bottled water brands produced or sold in Kumasi, Ghana," International Journal of Sustainable Development, vol. 2, pp. 2222-2232, 2013.

[17] C. C. Abnet, N. D. Freedman, F. Kamangar, M. F. Leitzmann, A. R. Hollenbeck, and A. Schatzkin, "Non-steroidal anti-inflammatory drugs and risk of gastric and oesophageal adenocarcinomas: results from a cohort study and a meta-analysis," British Journal of Cancer, vol. 100 , no. 3, p. 551, 2009.

[18] J.-S. Ren, F. Kamangar, D. Forman, and F. Islami, Pickled Food and Risk of Gastric Cancer-A Systematic Review and Meta-Analysis of English and Chinese Literature, Cancer Epidemiology and Prevention Biomarkers, p. 0202, USA, 2012.

[19] D. C. Farrow, T. L. Vaughan, C. Sweeney et al., "Gastroesophageal reflux disease, use of $\mathrm{H} 2$ receptor antagonists, and risk of esophageal and gastric cancer," Cancer Causes and Control, vol. 11, no. 3, pp. 231-238, 2000.

[20] J. D. Ahsan, M. B. Terry, M. D. Gammon et al., "Cigarette smoking, body mass index, gastro-esophageal reflux disease, and non-steroidal anti-inflammatory drug use and risk of subtypes of esophageal and gastric cancers by P53 overexpression," Cancer Causes \& Control, vol. 20, no. 3, pp. 361-368, 2009.

[21] Z. Zhang, G. Xu, M. Ma, J. Yang, and X. Liu, "Dietary fiber intake reduces risk for gastric cancer: a meta-analysis," Gastroenterology, vol. 145, no. 1, pp. 113-120, 2013.

[22] A. Z. Aris, R. C. Y. Kam, A. P. Lim, and S. M. Praveena, "Concentration of ions in selected bottled water samples sold in Malaysia," Applied Water Science, vol. 3, no. 1, pp. 67-75, 2013.

[23] I. Mihayo and S. Mkoma, "Chemical Water Quality of Bottled drinking water brands marketed in Mwanza city, Tanzania," Research Journal of Chemical Sciences, vol. 2, pp. 21-26, 2012.

[24] S. Sasikaran, K. Sritharan, S. Balakumar, and V. Arasaratnam, "Physical, chemical and microbial analysis of bottled drinking water," Ceylon Medical Journal, vol. 57, 2012.

[25] A. Singla, H. Kundu, B. P, S. Singh, K. Singh, and S. Jain, "Physico-chemical and bacterial evaluation of packaged drinking water marketed in Delhi - potential public health implications," Journal of Clinical and Diagnostic Research: JCDR, vol. 8, no. 3, p. 246, 2014.

[26] A. J. Whelton, A. M. Dietrich, G. A. Burlingame, M. Schechs, and S. E. Duncan, "Minerals in drinking water: impacts on taste and importance to consumer health," Water Science and Technology, vol. 55, no. 5, pp. 283-291, 2007.

[27] M. Farhadkhani, M. Nikaeen, B. A. Adergani, M. Hatamzadeh, B. F. Nabavi, and A. Hassanzadeh, "Assessment of drinking water quality from bottled water coolers," Journal of Public Health, vol. 43, no. 5, pp. 674-681, 2014.

[28] A. Ilyas and T. Sarwar, "Assessment of physico-chemica! and biological quality of drinking water in the vicinity of Palosi Drain Peshawar," Pakistan Journal of Applied Sciences, vol. 3, pp. 58-65, 2003.

[29] O. Shittu, J. Olaitan, and T. Amusa, "Physico-chemical and bacteriological analyses of water used for drinking and swimming purposes in abeokuta, Nigeria," African Journal of Biomedical Research, vol. 11, 2008.

[30] A. Deb, Fundamentals of Biochemistry, New central book agency Pvt. ltd, Kolkata, India, 2014.

[31] M. A. Rahman, M. A. Salam, A. Salam, M. Roy, N. J. Ara, and A. S. Alam, "Mineral content of different bottled water available in Bangladesh: assessment of their compliance with current regulations," Journal of the Asiatic Society of Bangladesh, Science, vol. 38, no. 1, pp. 7-15, 2013.

[32] A. Waugh and A. Grant, Ross and Wilson Anatomy and Physiology in Health and Illness, Churchill Livingstone, London, UK, 2014.

[33] M. A. Saleh, E. Ewane, J. Jones, and B. L. Wilson, "Chemical evaluation of commercial bottled drinking water from Egypt," 
Journal of Food Composition and Analysis, vol. 14, no. 2, pp. 127-152, 2001.

[34] A. Alsulaili, M. Al-Harbi, K. Al-Tawari, M. Hatamzadeh, B. F. Nabavi, and A. Hassanzadeh, "Physical and chemical characteristics of drinking water quality in Kuwait: tap vs. bottled water," Journal of Engineering Research, vol. 3, no. 1, 2014.

[35] M. Mohsin, S. Safdar, F. Asghar, and F. Jamal, "Assessment of drinking water quality and its impact on residents health in Bahawalpur city," International Journal of Humanities and Social Science, vol. 3, no. 15, 2014.

[36] Y. W. Chen, C. Y. Yang, C. F. Huang, D. Z. Hung, Y. M. Leung, and S. H. Liu, "Heavy metals, islet function and diabetes development," Islets, vol. 1, no. 3, pp. 169-176, 2009.

[37] S. Martin and W. Griswold, "Human health effects of heavy metals," Environmental Science and Technology Briefs for Citizens, vol. 15, pp. 1-6, 2009.

[38] A. Menke, S. Casagrande, L. Geiss, and C. C. Cowie, "Prevalence of and trends in diabetes among adults in the United States," JAMA, vol. 314, no. 10, pp. 1021-1029, 2014.

[39] K. Kasprzak, F. W. Sunderman, and K. Salnikow, "Nickel carcinogenesis," Mutation Research/Fundamental and Molecular Mechanisms of Mutagenesis, vol. 533, no. 1-2, pp. 67-97, 2003.

[40] F. H. Nielsen, K. Yokoi, and E. O. Uthus, "The essential role of nickel affects physiological functions regulated by the cyclicGMP signal transduction system," Metal Ions in Biology and Medicine International Symposium, pp. 29-33, John Libbey, Europe, France, 2002.

[41] H. Wintz, T. Fox, and C. Vulpe, "Responses of plants to iron, zinc and copper deficiencies," Biochemical Society Transactions, vol. 30, no. 4, pp. 766-768, 2002.

[42] A. B. G. Lansdown, "Critical observations on the neurotoxicity of silver," Critical Reviews in Toxicology, vol. 37, no. 3, pp. 237-250, 2007.

[43] A. B. Lansdown, "Silver in Health Care: Antimicrobial Effects and Safety in Use," Biofunctional Textiles and the Skin, Karger Publishers, Basel, Switzerland, 2006.

[44] S. Johnson and C. DeBiase, "Concentration levels of fluoride in bottled drinking water," Journal of Dental Hygiene, vol. 77, no. 3, pp. 161-167, 2003.

[45] B. Gautam and R. Adhikari, "Comparison of membrane filtration and replica plate technique to detect fecal coliform," Medical Journal of Shree Birendra Hospital, vol. 17, no. 2, pp. 25-31, 2018a. 